This is the author's final, peer-reviewed manuscript as accepted for publication. The publisher-formatted version may be available through the publisher's web site or your institution's library.

\title{
Field evaluations on soil plant transfer of lead from an urban garden soil
}

Chammi P. Attanayake, Ganga M. Hettiarachchi, Ashley Harms, DeAnn Presley, Sabine Martin, Gary M. Pierzynski

\section{How to cite this manuscript}

If you make reference to this version of the manuscript, use the following information:

Attanayake, C. P., Hettiarachchi, G. M., Harms, A., Presley, D., Martin, S., \& Pierzynski, G. M. (2014). Field evaluations on soil plant transfer of lead from an urban garden soil. Retrieved from http://krex.ksu.edu

\section{Published Version Information}

Citation: Attanayake, C. P., Hettiarachchi, G. M., Harms, A., Presley, D., Martin, S., \& Pierzynski, G. M. (2014). Field evaluations on soil plant transfer of lead from an urban garden soil. Journal of Environmental Quality, 43(2), 475-487.

Copyright: Copyright (C) American Society of Agronomy, Crop Science Society of America, and Soil Science Society of America.

Digital Object Identifier (DOI): doi:10.2134/jeq2013.07.0273

Publisher's Link: https://www.agronomy.org/publications/jeq/articles/43/2/475

This item was retrieved from the K-State Research Exchange (K-REx), the institutional repository of Kansas State University. K-REx is available at http://krex.ksu.edu 
Field Evaluations on Soil Plant Transfer of Lead from an Urban Garden Soil

Chammi P. Attanayake ${ }^{1,2}$, Ganga M. Hettiarachchi ${ }^{{ }^{*}}$, Ashley Harms ${ }^{1}$, DeAnn Presley ${ }^{1}$, Sabine Martin ${ }^{1}$, Gary M. Pierzynski ${ }^{1}$

${ }^{1}$ Department of Agronomy, Throckmorton Plant Sciences Center, Kansas State University, Manhattan, KS 66506, USA

${ }^{2}$ Department of Soil Science, Faculty of Agriculture, University of Peradeniya, Peradeniya 20400, Sri Lanka

*Corresponding Author (ganga@ksu.edu)

Contribution no. 13-364-J from the Kansas Agric. Exp. Stn. 


\begin{abstract}
Lead $(\mathrm{Pb})$ is one of the most common contaminants in urban soils. Gardening in contaminated soils can result in $\mathrm{Pb}$ transfer from soil to humans through vegetable consumption and unintentional direct soil ingestion. A field experiment was conducted in 2009 and 2010 in a community urban garden with soil total $\mathrm{Pb}$ concentration of 60 to $300 \mathrm{mg}$ $\mathrm{kg}^{-1}$. The objectives of this study were to evaluate soil-plant transfer of $\mathrm{Pb}$, the effects of incorporation of a leaf compost as a means of reducing $\mathrm{Pb}$ concentrations in vegetables and the bioaccessibility of soil $\mathrm{Pb}$, and the effects of vegetable cleaning techniques on the $\mathrm{Pb}$ concentrations in the edible portions of vegetables. The amount of compost added was $28 \mathrm{~kg}$ $\mathrm{m}^{-2}$. The tested plants were Swiss chard, tomato, sweet potato, and carrots. The vegetable cleaning techniques were kitchen cleaning, laboratory cleaning, and peeling. Compost addition diluted soil total $\mathrm{Pb}$ concentration by $29-52 \%$. Lead concentrations of the edible portions of vegetables, except carrot, were below the maximum allowable limits of $\mathrm{Pb}$ established by FAO and WHO. Swiss chard and tomatoes subjected to kitchen cleaning had higher $\mathrm{Pb}$ concentrations than laboratory-cleaned plants. Cleaning methods did not affect $\mathrm{Pb}$ concentrations in carrots. Bioaccessible $\mathrm{Pb}$ in the compost-added soils was $20-30 \%$ less than that of the no-compost soils; compost addition reduced the potential of transferring soil $\mathrm{Pb}$ to humans via vegetable consumption and direct soil ingestion. Thorough cleaning of vegetables further reduced the potential of transferring soil $\mathrm{Pb}$ to humans.
\end{abstract}

Keywords: urban soil, lead, soil-plant transfer, bioaccessibility

\title{
Introduction
}

Use of vacant lands in urban and suburban areas for vegetable production is growing. About 15\% of the world's food is produced in urban areas (USDA, 2012). Urban agriculture has the ability to provide a substantial proportion of local food demand, because most of the 
produce is used for household consumption and the rest is sold in local markets. This helps alleviate the issue of food deserts in urban areas, at least seasonally. Many of these urban gardens are subdivided into small plots that are managed by individuals, families, or small groups. Community gardening improves social cohesion and the awareness of ecosystem (Hynes and Genevieve, 2004).

Urban lands often were previously used residential, industrial, and commercial activities. Using urban lands for food production is challenging, because the quality of urban soil is poor for growing plants; and urban soils generally have a high bulk density, low nutrient and organic C content, and low biological activity (Jim, 1998). Mielke et al. (1983) reported that urban soils may contain higher concentrations of potentially toxic trace elements based on a study done in metropolitan Baltimore. These trace elements can originate from lead-based paint; burning of fossil fuels, including leaded gasoline (before the 1970s); and lead-arsenate pesticides (Klein, 1972; Carey et al., 1980; Turer et al., 2001; Zhai et al; 2003). The possibility of urban soils containing potentially toxic trace elements is a perceived obstacle to developing urban gardens. Lead is one of the most common potentially toxic trace metals in urban soils. Elevated $\mathrm{Pb}$ in the environment can increase blood $\mathrm{Pb}$ levels in children (Lanphear and Roghmann, 1997). About 310,000 U.S. children between the ages of 1 and 5 years are believed to have blood Pb levels at or greater than $10 \mu \mathrm{g} \mathrm{dL}^{-1}$ (ATSDR, 2007), which was the blood $\mathrm{Pb}$ level of concern recommended by the United States Center for Disease Control and Prevention (CDC). If the blood $\mathrm{Pb}$ concentrations of many children are above the level of concern, community-wide primary lead poisoning prevention activities should be implemented. In 2012, CDC reduced the definition of elevated blood $\mathrm{Pb}$ in children from $10 \mu \mathrm{g} \mathrm{dL}{ }^{-1}$ to $5 \mu \mathrm{g} \mathrm{dL}^{-1}$ based on CDC's Advisory Committee on Childhood Lead Poisoning Prevention recommendations (ACCLPP, 2012). 
Soil $\mathrm{Pb}$ can transfer to humans through soil ingestion, consumption of $\mathrm{Pb}$-contaminated foods, and inhalation of $\mathrm{Pb}$-containing soil particles. The amount of $\mathrm{Pb}$ that can transfer through inhalation is minute compared with the other two pathways (Davies et al., 1990); of those, soil ingestion is the most significant (Lanphear and Roghmann, 1997). Plant absorption and accumulation of soil $\mathrm{Pb}$ is lower than other potentially toxic trace elements such as $\mathrm{Cd}$ and $\mathrm{Se}$, mainly because of comparatively low concentrations of free $\mathrm{Pb}\left(\mathrm{Pb}^{+2}\right)$ in the soil solution. When $\mathrm{Pb}$ is absorbed by plant roots, it can precipitate as $\mathrm{Pb}$-phosphate forms in root cells and in xylem because of high $\mathrm{P}$ concentration and moderate $\mathrm{pH}$ in the root cells. In Pdeficient soils, $\mathrm{Pb}$ precipitation in the root cells is limited and $\mathrm{Pb}$ is transferred to shoots efficiently. Under such conditions, plants may show high Pb absorption (Foy et al. 1978), so natural translocation limits may be more important than uptake limits from the acidified rhizosphere. Consumption of vegetables grown in $\mathrm{Pb}$-contaminated soils may cause adverse health effects, but very little literature supports this idea. Especially in urban areas, plants may be superficially contaminated by the atmospheric deposition of $\mathrm{Pb}$-containing particulates from contaminated soils or other atmospheric emissions. Combustion of leaded gasoline releases $\mathrm{Pb}$-containing particulates into the atmosphere, and those particulates may deposit on plants that are grown close to major roads. Although leaded gasoline has been banned in many developed countries, it is still used in developing countries. Nabulo et al. (2006) found higher $\mathrm{Pb}$ concentrations in vegetables grown along major highways in Kampala City, Uganda; furthermore, they observed a significant difference in $\mathrm{Pb}$ concentrations in unwashed and washed leafy vegetables grown in urban gardens (Nabulo et al., 2010). They analyzed $\mathrm{Pb}$ concentrations of 15 leafy vegetables in several urban gardens that had $\mathrm{Pb}$ concentrations ranging from 9 to $770 \mathrm{mg} \mathrm{kg}^{-1}$ near Kampala City, Uganda. Washed leafy vegetables had 35\% lower $\mathrm{Pb}$ concentration than unwashed vegetables. 
Bioavailability means the portion of a substance or element in a soil that is available for absorption into living organisms, such as humans, animals, or plants. Bioavailability of soil $\mathrm{Pb}$ cannot be explained solely by the total $\mathrm{Pb}$ concentration; rather, it largely depends on speciation of $\mathrm{Pb}$ in soil (Davis et al., 1992; Ge et al., 2000) and other site-specific soil chemistry (Hettiarachchi and Pierzynski, 2004). Soil pH, soil organic matter content (Sauve et al., 1998), total $\mathrm{Pb}$ concentration, and soluble $\mathrm{P}$ concentration (Hettiarachchi et al., 2000) collectively affect soil $\mathrm{Pb}$ speciation. Speciation of soil $\mathrm{Pb}$ can be altered by changing soil chemical properties through adding amendments to soils. Phosphorous fertilizers, Mn oxides, and organic matter (e.g., compost, straw, and manure) have been tested for their ability to reduce the bioavailability of $\mathrm{Pb}$ in soils. Adding $\mathrm{P}$ fertilizer increases soil-available $\mathrm{P}$ and results in the formation of $\mathrm{Pb}$ pyromorphite-like minerals, thereby immobilizing soil $\mathrm{Pb}(\mathrm{Ma}$ et al., 1995; Hettiarachchi et al., 2000; Brown et al., 2003).

Speciation and bioavailability of $\mathrm{Pb}$ in soils amended with organic matter depends on the composition of the organic matter and soil chemistry. High Fe and Mn concentrations in biosolids reduce bioavailability of soil $\mathrm{Pb}$ (Brown et al., 2003). Increase of organic matter content and cation exchange capacity of soils as a result of compost application increase $\mathrm{Pb}$ sorption capacity of soil (Vega et al., 2009). In contrast, application of leaf compost increased soil $\mathrm{Pb}$ solubility at soil $\mathrm{pH}$ range of 6.5 to 8 by promoting formation and dissolution of organic-Pb complexes (Sauve et al., 1998). In the above context, soil- and amendmentspecific studies are essential to evaluate soil $\mathrm{Pb}$ bioavailability.

In addition to the direct effects of organic matter application on speciation of soil $\mathrm{Pb}$, organic matter also provides plant nutrients to soil and improve soil physical properties such as bulk density and water holding capacity (Chaoui et al., 2003; Gallardo-Lara and Nogales, 1987; Khaleel et al., 1981). This improves plant growth and leads to high biomass content. High biomass content itself dilutes any absorbed potentially toxic elements in the plants 
(Ekvall and Greger, 2003). Increased plant nutrients (N, P, and K) in Pb-contaminated urban soil have been found to reduce $\mathrm{Pb}$ concentration in lettuce (Sterrett et al., 1996). Similarly, low concentrations of $\mathrm{Pb}, \mathrm{Cd}$, and $\mathrm{Hg}$ were found in water spinach grown in a high-nutrient medium compared with water spinach grown in a low-nutrient medium (Gothberg et al., 2004).

Regardless of the effects of organic matter amendment on $\mathrm{Pb}$ bioavailability, the addition of locally available compost is a common practice among community gardeners, because it improves the workability of soil and plant growth; therefore, study of the ability of locally available compost to reduce bioavailability of $\mathrm{Pb}$ in urban soils would provide useful and important information to urban gardening communities. Although the acceptable blood $\mathrm{Pb}$ concentration level in children continues to decrease due to the subtle health effects of elevated blood $\mathrm{Pb}$ concentrations, only a limited number of studies focused on uptake of soil $\mathrm{Pb}$ by plants (Sterrett et al., 1996; Cui et al., 2004) and how that uptake transfers $\mathrm{Pb}$ to humans, and very little attention has been given to the importance of cleaning of vegetables grown in urban areas as an effective way to minimize soil $\mathrm{Pb}$ transfer to humans through vegetable consumption.

We conducted a field experiment in an urban community garden located on a formerly residential brownfield site with soil contaminated by $\mathrm{Pb}$ to assess vegetable crop uptake of $\mathrm{Pb}$, effectiveness of compost addition on $\mathrm{Pb}$ concentrations in vegetables, and the effects of vegetable-cleaning methods on $\mathrm{Pb}$ concentrations. The risk of $\mathrm{Pb}$ transfer via direct ingestion of garden soil also was evaluated using in-vitro bioaccessibility measurements.

\section{Materials and Methods}

A field study was performed in an urban community garden located in the Washington Wheatley neighborhood in Kansas City, Missouri. The garden is $42 \mathrm{~m} \times 37 \mathrm{~m}$, and the site 
was formerly occupied by four houses. The houses were demolished in the late 1970s. We suspect the source of soil $\mathrm{Pb}$ concentration is past use of leaded paint on the houses, although the use of leaded gasoline until 1971 and burning coal for heat also may have contributed. First, the site soils were screened approximately every 3 m using a XL3T Niton handheld $x-$ ray fluorescence (XRF) analyzer (Thermo Scientific, Billerica, MA) to detect the concentrations of potentially toxic trace elements. The initial XRF screening revealed that the site soils had elevated $\mathrm{Pb}$ concentrations; however, other potentially toxic trace element concentrations were not elevated. Spatial distribution of total $\mathrm{Pb}$ in the site soils was heterogeneous (Figure 1). Concentration of soil $\mathrm{Pb}$ ranged from $60 \mathrm{mg} \mathrm{kg}^{-1}$ to $300 \mathrm{mg} \mathrm{kg}^{-1}$. Two field test studies were conducted in 2009 and 2010. In 2009, the test plots were located in an area closer to the average urban background concentrations of $\mathrm{Pb}$ (77 to $157 \mathrm{mg} \mathrm{kg}^{-1}$ )

(USEPA, 2013), whereas in 2010, test plots were installed in an area with 186 to $388 \mathrm{mg} \mathrm{kg}^{-1}$ of $\mathrm{Pb}$ in the soils with the objective of gathering the maximum possible $\mathrm{Pb}$ uptake by the vegetables grown in the site soils.

\section{Field study}

Soil $\mathrm{pH}$ in urban garden soils that have elevated $\mathrm{Pb}$ should be maintained at a neutral level to minimize Pb solubility (Sterrett et al., 1996). Because soil pH was neutral (Table 1), this soil did not require $\mathrm{pH}$ adjustment or addition of lime. Mehlich-III P was high (Table 1), so no $\mathrm{P}$ fertilizer addition was recommended for this site. After excluding lime and $\mathrm{P}$ as our treatments, we selected locally available leaf compost (Missouri Organic, Kansas City, MO), which is commonly used by the gardeners in this area, as our field treatment. Some selected chemical properties of the compost are listed in Table 1.

In 2009, the experiment plot area was $2.4 \mathrm{~m} \times 3.7 \mathrm{~m}$, and in 2010 it was $5.2 \mathrm{~m} \times 8.8 \mathrm{~m}$. The plot area was demarcated from the rest of the garden using 20 -cm-high plastic plot 
dividers such that $15 \mathrm{~cm}$ of the dividers remained aboveground. Compost was added at $28 \mathrm{~kg}$ $\mathrm{m}^{-2}$ and mixed with the top $15 \mathrm{~cm}$ of soil, representing a compost:soil ratio of approximately 1:3 (v/v). Control plots with no compost were maintained. A leafy vegetable, a fruiting vegetable, and a tuber/root vegetable were grown to assess $\mathrm{Pb}$ uptake of vegetables in the presence and absence of compost treatment. In 2009, Swiss chard (Beta vulgaris; variety: Gator Perpetual Spinach), tomatoes (Solanum lycopersicum; variety: Biltmore) and sweet potatoes (Ipomoea batata; variety: Beauregard) were grown. In 2010, Swiss chard (variety: Burpee's Rhubarb Chard), tomatoes (variety: San Marzano) and carrots (Daucus carota; variety: Danvers \#126) were grown. Three blocks were prepared for each vegetable in 2009. The number of blocks was increased to four in 2010. Planting/sowing was done 16 days after incorporation of compost in both years. The recommended variety-specific spacing was maintained for all crops. At the end of the growing season, the edible portions of the plants were harvested as each plant type reached maturity. Representative soil samples were collected prior to adding compost, at planting, and at harvesting from each plot.

Soil chemical properties (available $N, P$, and $K$; electrical conductivity; soil $p H$, soil organic matter content; total $\mathrm{Pb}$ and easily extractable $\mathrm{Pb}$ )

Soil samples were analyzed for available N, P, and K; pH; electrical conductivity (EC); and organic C concentration. Available $\mathrm{N}$ (ammonia and nitrate) of soils was extracted by 1 $\mathrm{M} \mathrm{KCl}$ (Mulvaney, 1996). Available $\mathrm{K}$ was extracted by $1 \mathrm{M} \mathrm{NH}_{4} \mathrm{CH}_{3} \mathrm{COOH}(\mathrm{pH}=7.0)$ (Helmke and Spark, 1996). Available P was extracted by Mehlich-III (Mehlich, 1984) and analyzed calorimetrically using a flow injection analyzer (Lachat Instruments, Loveland, CO). The Walkley-Black procedure was used to determine organic $\mathrm{C}$ content in soils (Nelson and Sommers, 1996). Soil pH was determined using a 1:10 soil:deionized water mixture and a pH meter with an 'Accumet' pH/ATC Electrode and Accumet AP 115 meter (Fisher 
Scientific, Pittsburgh, PA). Soil-soluble salts were extracted using a 1:2 (v/v) soil:water extraction (Sonneveld and Van den Ende, 1971). EC of the extraction was measured with a Seven Easy conductivity meter S30 and Inlab 731 electrode (Mettler-Toledo Inc., Columbus, $\mathrm{OH})$. Dissolved organic carbon (DOC) concentrations were also determined in the 1:2(v/v) soil:water extractions using a total organic carbon analyzer that purged inorganic carbon of the extractions using $1 \mathrm{M} \mathrm{HCl}$ (Shimadzu, Columbia, MD).

Soil total $\mathrm{Pb}$ and other trace element concentrations $(\mathrm{Cr}, \mathrm{As}, \mathrm{Ni}, \mathrm{Cd}, \mathrm{Co}, \mathrm{Cu}$, and $\mathrm{Zn}$ ) were determined by EPA method SW846-3051A (USEPA, 2007b). To determine total trace element concentrations, $10 \mathrm{~mL}$ of trace metal-grade concentrated $\mathrm{HNO}_{3}$ was added to $0.5 \mathrm{~g}$ of soil and digested in a microwave digestion unit (MARSXpress, CEM Corporation, Matthews, NC). The temperature of the soil-acid mixture in the microwave digestion unit was increased to $165^{\circ} \mathrm{C}$ in $5.5 \mathrm{~min}$ in the first stage of the temperature program. In the second stage, temperature was further increased to $175^{\circ} \mathrm{C}$ in $4.5 \mathrm{~min}$ and the mixture was held at $175^{\circ} \mathrm{C}$ for $5 \mathrm{~min}$. A standard reference soil (NIST 2711a-Montana II) was digested along with every batch of test samples as a quality assurance/quality control (QA/QC) sample to evaluate digestion and analytical procedures. After filtering using the Whatman No. 42 filter papers, the solutions were analyzed for $\mathrm{Pb}$ using an inductively coupled plasma optical emission spectrophotometer (ICP-OES; Varian Inc., Foster City, CA).

Easily soluble, extractable $\mathrm{Pb}$ in the soils was extracted using $0.01 \mathrm{M} \mathrm{Sr}\left(\mathrm{NO}_{3}\right)_{2}$. The soil:0.01M $\mathrm{Sr}\left(\mathrm{NO}_{3}\right)_{2}$ solution ratio was $20 \mathrm{~g}: 40 \mathrm{~mL}$. After shaking the suspension for 1 hour, it was filtered using $0.45-\mu \mathrm{m}$ syringe filters. Resulting solutions were digested using the EPA SW846-3015A method (USEPA, 2007a) in the microwave digestion unit. This digestion minimized the matrix suppression of $\mathrm{Pb}$ absorbance in the Graphite Furnace Atomic Absorption Spectrometry (GF-AAS; Varian Inc., Foster City, CA) and equalized the matrix effects in the extractions of soils with and without added compost. The matrix suppression for 
the $\mathrm{Pb}$ absorbance in the GF-AAS was high in the compost-added soils compared with the soils without added compost. To overcome this issue, $1 \mathrm{~mL}$ of concentrated nitric acid was added to $9 \mathrm{~mL}$ of the filtered solution and the temperature was increased to $160^{\circ} \mathrm{C}$ in $10 \mathrm{~min}$, then to $170^{\circ} \mathrm{C}$ in the next $10 \mathrm{~min}$. The solution was again filtered using Whatman No. 42 filter paper and analyzed for $\mathrm{Pb}$ using GF-AAS.

\section{Cleaning methods for vegetables}

Produce in the 2010 study was divided into two portions and subjected to two cleaning procedures: laboratory cleaning and kitchen-style cleaning. Laboratory cleaning was done by

rinsing the produce with tap water, deionized (DI) water, $5 \mathrm{~g} \mathrm{~kg}^{-1}$ sodium lauryl sulfate $\left(\mathrm{CH}_{3}\right.$ $\left.\left(\mathrm{CH}_{2}\right)_{10} \mathrm{CH}_{2} \mathrm{OSO}_{3} \mathrm{Na}\right)$ solution, and again with $\mathrm{DI}$ water. This method was developed to remove all adhering soil dust particles from produce surfaces. Kitchen-style cleaning was done using only tap water to mimic the washing procedure of vegetables in a home kitchen. During kitchen cleaning, we removed all visible soil particles from the produce. In addition to these two methods, a portion of the lab-cleaned carrots was also peeled.

\section{Plant digestion}

Cleaned plant samples were chopped using a stainless steel knife, then dried at $70^{\circ} \mathrm{C}$ for 4 to 5 days. Dried plant materials were ground using a Willey Mini Mill-Arthur Thomas-type grinder (Thomas Scientific, Swedesboro, NJ). The sieve size was $250 \mu \mathrm{m}$ (60 mesh).

Plant samples were handled in a biosafety cabinet, class II type A2 (Esco Technologies Inc., St. Louis, MO), to avoid contamination by airborne dust in the laboratory. Ten milliliters of trace metal-grade concentrated $\mathrm{HNO}_{3}$ were added to $0.5 \mathrm{~g}$ of ground plant material and digested in a microwave digestion unit. The temperature of plant-acid mixture in the microwave digestion unit was increased to $200^{\circ} \mathrm{C}$ in $15 \mathrm{~min}$, and the mixture was held at 
$200^{\circ} \mathrm{C}$ for another $15 \mathrm{~min}$. All the plant samples were digested in duplicates. In each batch of digestion, two samples of standard reference plant material (NIST 1515-Apple leaves) and two blanks (concentrated $\mathrm{HNO}_{3}$ only) were included as QA/QC. Solutions were filtered using Whatman No. 42 filter papers and analyzed for Pb using GF-AAS. Different modifiers and temperature programs were used to enhance the signals (absorbance) of $\mathrm{Pb}$ in GF-AAS. The modifier used for analyzing $\mathrm{Pb}$ in Swiss chard and sweet potatoes was $1 \mathrm{mg} \mathrm{mL}^{-1} \mathrm{NH}_{4} \mathrm{H}_{2} \mathrm{PO}_{4}$ and $2 \%(\mathrm{w} / \mathrm{v}) \mathrm{H}_{3} \mathrm{PO}_{4}$ for tomatoes and carrots. Recoveries of spiked digested solutions with known concentrations of $\mathrm{Pb}$ were used as a guide to method development in GF-AAS. The recoveries of spiked samples were $93 \%$ for Swiss chard, $98 \%$ for tomatoes and sweet potatoes, and $103 \%$ for carrots.

\section{Simplified Physiologically Based Extraction Test (Simplified PBET)}

Ruby et al. (1996) suggested that PBET can be used in site-specific studies to assess exposure of humans to $\mathrm{Pb}$ (and As) in soils. This in-vitro method extracts the bioaccessible $\mathrm{Pb}$ of $\mathrm{Pb}$-contaminated soils in the human digestive system. Bioaccessible $\mathrm{Pb}$ levels were determined in the soil samples collected from tomato-growing plots at planting and at harvesting using the PBET procedure developed by Ruby et al. (1996) and simplified by Brown and Chaney (1997). We employed this method for two particle size fractions, $<250$ $\mu \mathrm{m}$ and $<2 \mathrm{~mm}$ (whole soil). The $<250 \mu \mathrm{m}$ size fraction represents the soil fraction that adheres to hand of a child and is recommended (USEPA, 2012); however, some scientists argue that larger soil particles can be ingested and may have a significant impact on $\mathrm{Pb}$ bioaccessibility (USEPA, 2007c). Furthermore, a complete characterization of soil fractions may be more consistent across sites (USEPA, 2007c). Based on these arguments, we also performed simplified PBET using $<2 \mathrm{~mm}$ soil fraction to estimate the bioaccessibility of the whole soil. 
The gastric solution was prepared by mixing $1.25 \mathrm{~g}$ of pepsin, $500 \mathrm{mg}$ of sodium Lmalate, $500 \mathrm{mg}$ of sodium citrate dihydrate, $500 \mu \mathrm{L}$ of trace metal-grade acetic acid, and 420 $\mu \mathrm{L}$ of $\mathrm{L}(+)$-lactic acid with $1 \mathrm{~L}$ of deionized water. The solution was acidified ( $\mathrm{pH}$ was about 2.00 ) with trace metal-grade concentrated $\mathrm{HCl}$ prior to adding the solution to the soil. One gram of soil and $100 \mathrm{~mL}$ of gastric solution were added to a $250-\mathrm{mL}$ polypropylene bottle. The gastric solution was heated to $37^{\circ} \mathrm{C}$ before adding it to the soil. The extraction was done at two initial $\mathrm{pH}$ values of the soil-gastric solution mixture, $1.5 \pm 0.02$ and $2.5 \pm 0.02$. $\mathrm{pH} 1.5$ represents fasting gastric $\mathrm{pH}$, and $\mathrm{pH} 2.5$ represents the intermediate stomach state between fasting and fed conditions (Ruby et al., 1996). The $\mathrm{pH}$ adjustment of the soil-gastric solution mixture was done by adding varying volumes of trace metal-grade concentrated $\mathrm{HCl}$. The soil-gastric solution mixture was shaken at $37^{\circ} \mathrm{C}$ at $100 \mathrm{rpm}$ for 1 hour, then the samples were filtered using $0.45 \mu \mathrm{m}$ syringe filters. A standard reference material (NIST 2711aMontana II soil) was subjected to this test at both $\mathrm{pH} 1.5$ and 2.5 with each batch of extraction (A batch consisted of 20 samples). Two blanks were also included in each extraction batch. Analysis of extractions for $\mathrm{Pb}$ was done by GF-AAS. The signal of the GFAAS was enhanced by using $2 \%(\mathrm{w} / \mathrm{v}) \mathrm{H}_{3} \mathrm{PO}_{4}$ as a modifier. Recovery of the spiked extraction with known concentration of $\mathrm{Pb}$ was $99 \%$.

\section{Statistical analysis}

SAS 9.2 statistical software was used (SAS Institute, 2010). The Pb concentrations of vegetables and bioaccessible $\mathrm{Pb}$ concentrations were transformed to log base 10 to achieve normal distribution prior to statistical analysis. One-way analysis of variance (ANOVA) using PROC GLM was performed to analyze the effect of compost addition on $\mathrm{Pb}$ concentrations in vegetables. Separate analyses were done for each vegetable. The design was a split-plot design with completely randomized block arrangement with three (in 2009) or 
four (in 2010) blocks: the main plot factor was compost (compost added and no compost), and the subplot factor was the cleaning techniques used. The effects of compost addition on bioaccessible $\mathrm{Pb}$ and \% bioaccessible $\mathrm{Pb}$ (i.e., [bioaccessible $\mathrm{Pb}$ concentration in $\mathrm{mg} \mathrm{kg}^{-1}$ / total soil $\mathrm{Pb}$ in $\left.\mathrm{mg} \mathrm{kg}^{-1}\right]^{* 100)}$ were analyzed using PROC GLM. Differences between bioaccessible $\mathrm{Pb}$, determined at 16 days (at planting time) and 105 days (at harvest time of tomatoes) after compost treatment were analyzed using a paired t-test by PROC TTEST procedure.

\section{Results and Discussion}

\section{Compost addition changed soil chemical properties}

As expected concentrations of plant nutrients in compost-added soils were significantly higher than in soils that did not receive compost (Table 1). During the growing season, available N, Mehlich III-P, and available K concentrations reduced in compost-added soils. In soils that did not receive compost, concentrations of available N, Mehlich III-P, and available $\mathrm{K}$ did not decrease throughout the growing season. Soil $\mathrm{pH}$ in compost-added and no-compost-added soils was in the neutral range; furthermore, as one would expect, compost addition improved the concentration of soil organic carbon and cation exchange capacity (Table 1).

We observed high biomass production in compost-added soils. For example, in 2010 the average fresh Swiss chard harvest in compost-added plots weighed $1.61 \mathrm{~kg} \mathrm{~m}^{-2}$ (standard error 0.19), whereas in the plots that did not receive compost it was $0.58 \mathrm{~kg} \mathrm{~m}^{-2}$ (standard error 0.12). We also observed that plants in compost-added plots grew faster, were healthier, and produced higher biomass contents than the plants in plots that did not receive compost. It is not the intention of this paper to discuss soil fertility aspects in detail; however, due to 
possible effects of poor nutrient status on plant $\mathrm{Pb}$ uptake (this was discussed later in the paper), we were interested in the soil fertility status of the soil.

Dilution of soil matrix after compost addition significantly reduced total $\mathrm{Pb}$ concentrations in soils, and this effect was immediate. After adding compost, initial soil total $\mathrm{Pb}$ concentrations were reduced by $29-52 \%$ (data not shown). In contrast, easily soluble $\mathrm{Pb}$ concentration, as estimated by $0.01 \mathrm{M} \mathrm{Sr}\left(\mathrm{NO}_{3}\right)_{2}$ extraction, was high in compost-added soils compared with no-compost soils (Table 5). Increased extractable $\mathrm{Pb}$ concentration in compost-added soils related to increased DOC concentration in the soils upon compost addition ( Table 1). Dissolved organic matter degrades over time and makes the dissolved $\mathrm{Pb}$ available for other reactions.

\section{Lead concentrations in vegetables}

All the vegetables had detectable amounts of $\mathrm{Pb}$ in their edible portions. From this point onward, the $\mathrm{Pb}$ concentration in plants refers to the $\mathrm{Pb}$ concentration in the edible portion: for tomatoes, it is the fruit; for Swiss chard, it is leaves; and for sweet potatoes and carrots, it is the root. No clear trend was observed for the relationship of $\mathrm{Pb}$ concentrations of vegetables to soil total $\mathrm{Pb}$ concentration (Figure 5). Compost addition increased the extractable $\mathrm{P}$ concentration in soils, as indicated by Mehlich III-P (Table 4 and 5). Although increased soluble $\mathrm{P}$ concentration can reduce the solubility of $\mathrm{Pb}$ in soils, there was no clear relationship between Mehlich III-P concentrations with the bioconcentration factors of the vegetables.

\section{Effects of compost addition}

The effects of compost addition on $\mathrm{Pb}$ concentrations in vegetable crops were determined after cleaning with the laboratory procedure, which aims to remove all adhering soil particles 
from the surface of the produce. In the 2009 study, compost addition did not significantly reduce $\mathrm{Pb}$ concentrations in any of the three vegetables (Table 4). The reason could be low soil total $\mathrm{Pb}$ concentrations $\left(77-157 \mathrm{mg} \mathrm{kg}^{-1}\right.$ ) that resulted in only mild elevation of $\mathrm{Pb}$ concentrations in vegetables. In 2010, test plots were established in comparatively high total$\mathrm{Pb}$ soils (186 to $\left.388 \mathrm{mg} \mathrm{kg}^{-1}\right)$ and, addition of compost significantly reduced $(\mathrm{P}<0.05) \mathrm{Pb}$ concentrations in Swiss chard and carrots (Table 5). In compost-added plots, $\mathrm{Pb}$ concentrations were 59\% lower in Swiss chard and 20\% lower in carrots compared with Swiss chard and carrots grown in soils that did not receive compost. Lead concentrations of tomatoes were not significantly different in compost-added and no compost-added soils. Concentrations of $\mathrm{Pb}$ in tomatoes (average of $\sim 0.07 \mathrm{mg} \mathrm{kg}^{-1}$-dry weight) may be too low to show the effect of compost addition.. In general, $\mathrm{Pb}$ bioconcentration factors express the proportion of soil total $\mathrm{Pb}$ concentrations absorbed by plants. Carrots and sweet potatoes had the highest bioconcentration factor, followed by Swiss chard, followed by tomatoes, supporting the fact that accumulation of $\mathrm{Pb}$ was highest in roots, followed by leaves, then fruits. This could be a result of translocation of $\mathrm{Pb}$ within the plant. Finster et al. (2004) found $\mathrm{Pb}$ concentration of tomato roots to be 33 times higher than that of the shoot and $>72$ times higher than that of the fruits in tomatoes grown in $\mathrm{Pb}$-contaminated $(3,740 \mathrm{mg} \mathrm{Pb} / \mathrm{kg})$ residential soils. Soil $\mathrm{P}$ concentration may affect translocation of $\mathrm{Pb}$ within a plant (Foy et al., 1978). When plants are grown in soils that have high $\mathrm{P}$ concentration, $\mathrm{Pb}$ phosphates precipitate in the root organelles. This limits the translocation of $\mathrm{Pb}$ from root to shoot. The moderate $\mathrm{pH}$ of the root cells and the xylem sap may assist $\mathrm{Pb}$ phosphate formation in roots.

The concentration of $\mathrm{Pb}$ in vegetables does not necessarily reflect total $\mathrm{Pb}$ uptake by that vegetable. Although compost addition reduced $\mathrm{Pb}$ concentrations in Swiss chard, it did not reduce its $\mathrm{Pb}$ uptake (total $\mathrm{Pb}$ ) (Table 6), demonstrating that increased plant biomass as a result of compost addition diluted $\mathrm{Pb}$ concentrations in Swiss chard. Similar results were 
observed by Ekvall and Greger (2003). They showed that increasing plant total biomass of seedlings of Pinus sylvestris as a response to physiological conditions in the environment diluted Cd concentrations in the plant, especially in the root. In our experiment, one nocompost plot for carrot produced $87 \%$ less root biomass than other no-compost plots because the soil was unusually compacted due to high clay content. This plot had the highest concentration of total soil $\mathrm{Pb}\left(387.9 \mathrm{mg} \mathrm{kg}^{-1}\right)$. The bioconcentration factor of carrots in this plot was 0.0206 , which was 1.8 times higher than the average bioconcentration factor of carrots harvested from the other three no- compost soils (i.e., 0.0112, Table 5). This result indicates that an increase of total biomass of vegetables could be an effective means of reducing potential $\mathrm{Pb}$ transfer to humans.

\section{Effects of vegetable cleaning methods}

Lead concentrations of vegetables determined after cleaning with different techniques were significantly different for Swiss chard and tomatoes, but not for carrots (Figure 4). Swiss chard cleaned with the kitchen cleaning method contained 2.6 to 4.6 times greater $\mathrm{Pb}$ concentrations than that cleaned with the lab cleaning method. Similarly, kitchen-cleaned tomatoes had 3.0 times greater $\mathrm{Pb}$ concentrations than lab-cleaned tomatoes.

Transfer of $\mathrm{Pb}$ from plants to humans could occur not only because of uptake of $\mathrm{Pb}$ by plants, but also because of contaminated soil particles that adhere to the plant surface or are embedded in the waxy outer layer of plants. Fruits, leaves, and non-woody stems such as aerial parts of higher plants have an extra cellular membrane called the cuticle that consists of soluble and polymerized lipid covers (Heredia and Dominguez, 2009). Sodium lauryl sulfate, used in the lab cleaning method, is an anionic surfactant. Anionic (and nonionic) surfactants have the ability to solubilize water-insoluble materials such as cutin and dissolve a larger portion of the cuticle barrier (Furmidge, 1959). By using the lab cleaning method, we may 
have effectively removed particles embedded in the plant surface by solubilizing the cutin lipid cover; therefore, lab-cleaned tomatoes and Swiss chard showed lower $\mathrm{Pb}$ concentrations. In contrast, cleaning methods did not significantly affect $\mathrm{Pb}$ concentrations in carrots. This can be explained by the absence of cuticle lipid layer on the roots. Peeling also did not statistically change $\mathrm{Pb}$ concentrations in carrots. When peeling, we removed a very thin outer layer of the carrots. Synchrotron-based x-ray fluorescence mapping has shown that the concentrations of $\mathrm{Pb}$ in the peel and the phloem of the carrot are low compared with the concentration of $\mathrm{Pb}$ in the inner xylem tissues of the carrots (Codling et al., 2007), which could explain the lack of difference in $\mathrm{Pb}$ concentrations of peeled carrots in this study.

\section{Comparison of plant $\mathrm{Pb}$ with maximum allowable levels}

When human health is concerned, it is important to interpret contaminant concentrations with respect to standard values of maximum allowable levels (MLs). The Codex Alimentarius Commission (CODEX), established by the Food and Agriculture Organization (FAO) and World Health Organization (WHO), develops international food standards, guidelines and codes of practice to protect the health of the consumers and ensure fair practices in the food trade. The CODEX committee on contaminants in food established or endorsed permitted maximum levels (MLs) or guidelines levels for contaminants and naturally occurring toxicants in food and feed and includes maximum levels for $\mathrm{Pb}$ concentrations in vegetables. We used these MLs as a guideline to compare concentrations of $\mathrm{Pb}$ in vegetables. It is important to note here that these limits are not developed based on bioavailability of $\mathrm{Pb}$ in food. Research has shown that $\mathrm{Pb}$ ingestion along with food reduces bioavailability of $\mathrm{Pb}$ in the digestive system (James et al., 1985: USEPA, 2003). Calcium and phosphates in the food may contribute to this reduction, but the exact mechanism is not 
understood (USEPA, 2003). CODEX MLs might have been developed considering the upper limit or the maximum potential health risk of consuming $\mathrm{Pb}$ contaminated vegetables.

According to the CODEX guidelines, the $\mathrm{ML}$ of $\mathrm{Pb}$ is $0.3 \mathrm{mg} \mathrm{kg}^{-1}$ of fresh matter for leafy vegetables and $0.1 \mathrm{mg} \mathrm{kg}^{-1}$ of fresh matter for fruiting vegetables and root/tuber vegetables (FAO/WHO-CODEX, 1995; 2010 amendment). Because we analyzed dried plant materials to determine $\mathrm{Pb}$ concentrations in the vegetables, for the convenience of interpreting results, we converted the above MLs to a dry weight basis. For Swiss chard, which is a leafy vegetable, the ML of $\mathrm{Pb}$ is $5.0 \mathrm{mg} \mathrm{kg}^{-1}$ of dry matter (assuming moisture content of Swiss chard was $94 \%$ ). The ML of $\mathrm{Pb}$ for tomatoesis $1.6 \mathrm{mg} \mathrm{kg}^{-1}$ dry matter (assuming moisture content of 94\%; Pennington et al., 1998), and for carrots and sweet

potatoes, the ML is $1.5 \mathrm{mg} \mathrm{kg}^{-1}$ of dry matter (assuming the moisture contents of $93 \%$; Pennington et al., 1998).

Average concentrations of $\mathrm{Pb}$ in Swiss chard and tomatoes in both compost-added and no-compost soils were lower than the $\mathrm{ML}$ for $\mathrm{Pb}$ in leafy vegetables and fruiting vegetables both in 2009 and 2010 test plots (Figure 4). Concentrations of $\mathrm{Pb}$ in sweet potatoes and carrots were close to the ML for $\mathrm{Pb}$ in tuber and root crops. Consumption of leafy and fruiting vegetables grown at this site does not carry any health risk, but consumption of root and tuber crops grown at this site potentially carries the risk of ingesting harmful levels of $\mathrm{Pb}$.

\section{Bioaccessibility of soil $\mathrm{Pb}$}

Simplified PBET estimates the bioaccessibility of $\mathrm{Pb}$ in the event of direct ingestion of soil. Brown et al. (2003) showed that bioaccessible Pb determined by simplified PBET, which is also known as rapid PBET, correlates well with Pb concentrations in rat bones (at $\mathrm{pH} 1.5, \mathrm{R}^{2}=0.84$; at $\left.\mathrm{pH} 2.3, \mathrm{R}^{2}=0.90\right)$. Furthermore, this correlation is stronger than the 
correlation between bioaccessible $\mathrm{Pb}$ recovered by the original PBET procedure developed by Ruby et al. (1996) and $\mathrm{Pb}$ concentrations in rat bones (at $\mathrm{pH} 2.0, \mathrm{R}^{2}=0.66$ ).

Ingestion of food dilutes and buffers the $\mathrm{pH}$ of the gastric solution, making it less acidic at fed states (Davenport, 1984). Bioaccessible $\mathrm{Pb}$ as determined at $\mathrm{pH} 2.5$ was $81 \%$ (compost-added soils) and 79\% (no-compost soils) lower than the bioaccessible $\mathrm{Pb}$ determined at $\mathrm{pH} 1.5$ (Tables 2 and 4). This was expected, because dissolution of $\mathrm{Pb}$ is highly $\mathrm{pH}-$ dependent. Similarly, a $65 \%$ reduction in dissolution of soil $\mathrm{Pb}$ was observed when $\mathrm{pH}$ of the soil-gastric solution increased from 1.3 to 2.5 (Ruby et al., 1996). Soil Pb bioaccessibility determined at $\mathrm{pH} 2.3$ correlate well with bioavailability determined using in vivo methods (Medlin, 1997; Brown et al., 2003). Researchers have shown that the reduction of $\mathrm{Pb}$ bioaccessibility in the amended soils was prominent at $\mathrm{pH} 2.5$ or 2.2 (Brown et al., 2004; Ryan et al., 2004) and that pH 1.5 overestimates the bioavailability of soil Pb (Brown et al., 2003; Smith et al., 2011). Drexler and Brattin (2007) recommended using $\mathrm{pH} 1.5$, because this $\mathrm{pH}$ provides greatest improvement in predicting relative bioavailability and limits the risk of underestimating.

In this study, regardless of the extraction $\mathrm{pH}$, the majority of soil $\mathrm{Pb}$ did not dissolve in the gastric solution. Only $33-44 \%$ of total $\mathrm{Pb}$ in the soils that did not receive compost and $21-32 \%$ of total $\mathrm{Pb}$ in the soils that received compost were dissolved in the gastric solution at $\mathrm{pH} 1.5$, whereas 3.5 to $6.0 \%$ of total $\mathrm{Pb}$ was dissolved in the gastric solution at $\mathrm{pH} 2.5$. This result indicated that the majority of soil $\mathrm{Pb}$ at this site is not bioaccessible. Past research also observed that a considerable portion of $\mathrm{Pb}$ in urban soils was not bioaccessible (Yang et al., 2001; Brown et al., 2003; Farfel et al., 2005). The fraction of bioaccessible $\mathrm{Pb}$ can be different from one site to another, depending on $\mathrm{Pb}$ speciation and other soil chemical properties. Unpublished $\mathrm{x}$-ray absorption data from our laboratory shows most $\mathrm{Pb}$ in this soil was in either ferrihydrite adsorbed- or humic acid adsorbed forms. Smith et al. (2011) 
showed that soil $\mathrm{Pb}$ was strongly associated with Fe oxyhydroxide minerals or the soil organic fraction in a study conducted with urban soils. Researchers have found that outersphere and inner-sphere adsorption are two major processes of $\mathrm{Pb}$ immobilization in soils (Zimdahl and Skogerbo, 1977; Strawn and Sparks, 2000). In urban soils, the concentration of $\mathrm{Pb}$ generally may not reach high enough levels to expect significant formation of $\mathrm{Pb}$ precipitates; however, we cannot rule out the possibility of localized $\mathrm{Pb}$ precipitation when concentration of $\mathrm{Pb}$ and other constituents of the common $\mathrm{Pb}$ minerals in soils (e.g., carbonates and phosphates) are high (Zimdahl and Skogerbo, 1977; Cotter-Howells, 1996).

\section{Effects of compost addition on bioaccessible Pb after 16 days of compost addition as} determined at $\mathrm{pH} 1.5$

Compost addition reduced bioaccessible $\mathrm{Pb}$ in the $<2 \mathrm{~mm}$ fraction (Table 2). In the $<250$ $\mu \mathrm{m}$ fraction, bioaccessible $\mathrm{Pb}$ was not statistically different in soils with compost and without compost. Dilution of soil total $\mathrm{Pb}$ and increase in soil-available $\mathrm{P}$ upon compost addition may have caused the reduction of soil bioaccessible $\mathrm{Pb}(<2 \mathrm{~mm}$ fraction $)$ in the compost-added soils. Figure 2 shows a comparatively high relationship $\left(\mathrm{R}^{2}=0.71\right)$ between soil total $\mathrm{Pb}$ and bioaccessible $\mathrm{Pb}$ at $1.5 \mathrm{pH}$. This dilution of soil total $\mathrm{Pb}$ in compost-added soils was not intense in the $<250 \mu \mathrm{m}$ fraction, because most of the compost materials were removed with larger particles during sieving. The percentage of bioaccessible $\mathrm{Pb}$ is a measure of bioaccessibility independent from soil total $\mathrm{Pb}$; therefore, percentage bioaccessibility values are not influenced by the dilution effect of soil total $\mathrm{Pb}$ upon compost addition. The percentage of bioaccessible $\mathrm{Pb}$ in both $<2 \mathrm{~mm}$ and $<250 \mu \mathrm{m}$ fractions was significantly lower in the compost-added soils than in the soils that did not receive compost (Table 2). This result suggests that in addition to the dilution effect, compost reduced the bioaccessibility of soil $\mathrm{Pb}$. Increased soil-available $\mathrm{P}$ upon compost addition (average available $\mathrm{P}$ concentrations 
were $68 \mathrm{mg} \mathrm{kg}^{-1}$ in the soils that did not receive compost and $438 \mathrm{mg} \mathrm{kg}^{-1}$ in the soils that receive compost) might partially contribute to the decreased percentage of bioaccessible soil $\mathrm{Pb}$ in compost-added soils. Figure 3 shows the relationship of bioaccessible $\mathrm{Pb}$ to available $\mathrm{P}$ concentrations. Reductions in $\mathrm{Pb}$ bioaccessibility with increases in available $\mathrm{P}$ concentrations have been observed by past researchers (Hettiarachchi et al., 2000; Yang et al., 2001; Hettiarachchi et al., 2003). Available $\mathrm{P}$ reacts with $\mathrm{Pb}$ in soil and forms relatively stable $\mathrm{Pb}$ species such as hydroxypyromorphite (or hydroxypyromorphite-like minerals) and chloropyromorphites (or chloropyromorphite-like minerals) (Hettiarachchi et al., 2000). In addition to total soil $\mathrm{Pb}$ and soil-available $\mathrm{P}$ concentrations, soil total organic $\mathrm{C}$ (Ruby et al., 1996) also affect bioaccessibility of soil Pb. Ruby et al. (1996) argued that total organic $\mathrm{C}$ in soil increases the bioaccessibility of $\mathrm{Pb}$ as estimated by the stomach phase of the original PBET procedure (Ruby et al. [1996] consisted of two phases, stomach and intestinal). The authors explain that organic $\mathrm{C}$ provides additional sorptive surfaces that may readily desorb $\mathrm{Pb}$ in the gastric environment. Although total organic $\mathrm{C}$ concentrations were higher in the compost-added soils $(3.2 \%)$ than in soils without added compost $(2.1 \%)$ in our study, the effects of soil organic $\mathrm{C}$ on $\mathrm{Pb}$ bioaccessibility might have been counteracted by the effects of increased P concentrations in the compost-added soils. Further, Fe and Mn oxides in compost reduce bioaccessibility of soil $\mathrm{Pb}$ (Hettiarachchi et al., 2000; Brown et al., 2003). In a recent study, Brown et al. (2012) demonstrated that not only the Fe concentration but also the reactivity of $\mathrm{Fe}$ in the biosolids affected the bioaccessibility of $\mathrm{Pb}$ in soils. The compost we used in our experiment was a leaf-based compost, which had only $3.8 \mathrm{~g} \mathrm{~kg}^{-1}$ total Fe and 0.2 $\mathrm{g} \mathrm{kg}^{-1}$ of total Mn, which were fairly low concentrations compared with the composted biosolids used by Brown et al. (2003) and Brown et al. (2012). Therefore, the higher concentration of soil-available $\mathrm{P}$ was the predominant factor that reduced the percentage of $\mathrm{Pb}$ bioaccessibility in compost-added soils compared with the soils without added compost. 
Effects of compost addition on bioaccessible Pb after 16 days of compost addition as determined at $\mathrm{pH} 2.5$

Compost addition did not reduce bioaccessible $\mathrm{Pb}$ at $\mathrm{pH} 2.5$ in both $<2 \mathrm{~mm}$ and $<250$ $\mu \mathrm{m}$ fractions (Table 3). To improve the statistics, we did PBET extraction at $\mathrm{pH} 2.5$ in soils collected from all 12 blocks (4 blocks per each vegetable) after 16 days of compost addition, but we still did not see a significant reduction in bioaccessible $\mathrm{Pb}$ upon compost addition (Table 3 shows only the results of 4 blocks). Unlike at $\mathrm{pH} 1.5$, the dilution of soil total $\mathrm{Pb}$ as a result of compost addition seemed to have a minimal effect on reducing bioaccessible $\mathrm{Pb}$ at $\mathrm{pH}$ 2.5. This result was supported by the poor relationship between bioaccessible $\mathrm{Pb}$ and soil total $\mathrm{Pb}$ at $\mathrm{pH} 2.5$ (Figure 2).

Percentage of bioaccessible $\mathrm{Pb}$ was significantly lower in compost-added soils than in soils that did not receive compost in the $<250 \mu \mathrm{m}$ fraction $(\mathrm{P}<0.15 ; \mathrm{p}=0.12)$. This was not significant in $<2 \mathrm{~mm}$ fraction (Table 3 ). As previously explained, lowering the percentage of bioaccessible $\mathrm{Pb}$ in compost-added soils can be attributed to enhanced available $\mathrm{P}$ in soil through compost addition. Figure 3 also shows a poor relationship of available P and percentage of bioaccessible $\mathrm{Pb}$ in the $<2 \mathrm{~mm}$ fraction. In this size fraction, the effects of enhanced $\mathrm{P}$ on percentage of bioaccessible $\mathrm{Pb}$ could have been masked by increased $\mathrm{Pb}$ solubility in the compost-added soils as a result of elevated concentrations of DOC. The effects of DOC on percentage of bioaccessible $\mathrm{Pb}$ could be minimal in the $<250 \mu \mathrm{m}$ fraction and not high enough to mask the effects of enhanced available $\mathrm{P}$ because the proportion of compost material in this fraction was relatively low. Concentration of DOC at $\mathrm{pH} 1.5$ was expected to be lower than that at $\mathrm{pH}$ 2.5. Past research found that at lower $\mathrm{pH}$, the dissolution of soil organic carbon was less than that at high pH (You et al., 1999). Therefore, the increase 
in $\mathrm{Pb}$ solubility by DOC might not have been high enough to override the effects of elevated available $\mathrm{P}$ concentration on the percentage of bioaccessible $\mathrm{Pb}$ at $\mathrm{pH} 1.5$.

\section{Change of bioaccessibility of soil Pb over the growing period}

We used the percentage of bioaccessible $\mathrm{Pb}$ instead of bioaccessible $\mathrm{Pb}$ to evaluate this time effect because bioaccessible $\mathrm{Pb}$ depends on the total $\mathrm{Pb}$ concentration, and the total $\mathrm{Pb}$ concentrations in two soil samples (16 days and 105 days after adding compost) collected from the same plot can be different depending on the variability of the total $\mathrm{Pb}$ concentration at the site: Average difference and standard error of difference in total $\mathrm{Pb}$ concentrations of the samples collected 16 days after compost addition (at planting) and 105 days after compost addition (at harvesting tomatoes) were $24 \mathrm{mg} \mathrm{kg}^{-1}$ and $5.4 \mathrm{mg} \mathrm{kg}^{-1}$, respectively. These are low and acceptable for a field experiment. The change in bioaccessible $\mathrm{Pb}$ concentration throughout the growing period was analyzed only in the compost-added soils 16 days and 105 days after compost addition to evaluate the effects of compost addition on the percentage of bioaccessible $\mathrm{Pb}$ through time. Percentage of bioaccessible $\mathrm{Pb}$ in compost-added soils did not decrease significantly over time when measured at $\mathrm{pH} 1.5$ in both $<2 \mathrm{~mm}$ and $<250 \mu \mathrm{m}$ fractions (Table 2). As discussed above, high available $\mathrm{P}$ concentration reduced the percentage of bioaccessible $\mathrm{Pb}$ in the compost added soils. A small reduction in the percentage of bioaccessible $\mathrm{Pb}$ in phosphate-applied soils over time was observed in previous research (Hettiarachchi et al., 2000; 2001), which could be because either the majority of the bioaccessible $\mathrm{Pb}$ reduction happened within the first 16 days of compost addition or the $\mathrm{Pb}-\mathrm{P}$ reaction happened under the gastric phase of PBET and was not affected by the contact time of $\mathrm{Pb}$ and $\mathrm{P}$ in the field, as in Hettiarachchi et al. (2001).

When bioaccessibility was measured at $\mathrm{pH} 2.5$, the percentage of bioaccessible $\mathrm{Pb}$ seemed to decrease over time in compost-added soils in the $<2 \mathrm{~mm}$ fraction, but at a low 
significance level $(\mathrm{p}<0.15 ; \mathrm{p}=0.11$; Table 3$)$. This was not significant in the $<250 \mu \mathrm{m}$ fraction. At $\mathrm{pH} 2.5$, solubility of $\mathrm{Pb}$ due to $\mathrm{DOC}$ was a prominent factor that affected the percentage of bioaccessible soil $\mathrm{Pb}$, as discussed earlier. Dissolved organic carbon introduced by compost addition decreased over time; therefore, we expect lower Pb solubility in the soils collected 105 days after compost addition compared with 16 days after compost addition. This could explain the significant reduction in the percentage of bioaccessible of $\mathrm{Pb}$ in the $<2$ $\mathrm{mm}$ fraction over time at $\mathrm{pH} 2.5$. The representation of compost material in the $<250 \mu \mathrm{m}$ fraction would be low, as mentioned before. Therefore, the DOC effect on $\mathrm{Pb}$ bioaccessibility could be minimal in this fraction and could explain the lack of significant difference in percentage of bioaccessible of $\mathrm{Pb}$ in this fraction of compost-added soils over time.

A significant decrease in percentage of bioaccessible $\mathrm{Pb}$ in soils with compost added was observed compared with soils without added compost after 105 days of compost addition in the $<250 \mu \mathrm{m}$ fraction. This result indicated that the effects of enhanced available $\mathrm{P}$ in compost-added soils lasted $>105$ days. This difference was not significant in the $<2 \mathrm{~mm}$ fraction, which can be attributed to the higher variability of the bioaccessibility values observed in this size fraction compared with the $<250 \mu \mathrm{m}$ fraction.

\section{Conclusions}

The extent of $\mathrm{Pb}$ contamination was highly variable within a small area. Compost addition diluted initial total soil $\mathrm{Pb}$ concentrations, indicating that the continuous addition of compost would lower total $\mathrm{Pb}$ concentration in soils significantly. Compost addition reduced the potential risk of soil $\mathrm{Pb}$ transfer to humans indirectly through consumption of vegetables grown at this site and directly through soil ingestion by decreasing plant $\mathrm{Pb}$ and bioaccessible $\mathrm{Pb}$ concentrations. Dilution of soil total $\mathrm{Pb}$ concentration and increase in soil-available $\mathrm{P}$ followed by compost addition helps reduce soil $\mathrm{Pb}$ transfer to humans through direct 
ingestion of soils. In addition, compost addition helps maintain good soil nutrient status in soils. Maintaining good soil fertility and thereby increasing biomass production diluted $\mathrm{Pb}$ concentrations in the vegetables. The highest concentrations of $\mathrm{Pb}$ in edible portions were found in root/tuber crops, followed by leafy and fruiting vegetables. Thorough cleaning and removal of soil/dust particles deposited on edible portions of vegetables, especially leafy and fruiting vegetables, further reduces food chain transfer of soil $\mathrm{Pb}$ to humans.

\section{Acknowledgements}

The authors thank the United States Environmental Protection Agency for providing funding for this research (Grant No. TR-83416101). The authors would like to acknowledge Edward Carey (formerly at Kansas State University), Blasé Leven (Center for Hazardous Substance Research at Kansas State University), Larry Erickson (Department of Chemical Engineering, Kansas State University) and Jacob Wagner (University of Missouri, Kansas City) for their help. The authors would also like to thank Marlon Hammond and the Washington Wheatley neighborhood community gardeners in Kansas City, Missouri.

\section{References}

ACCLPP. 2012. Low level lead exposure harms children: A renewed call for primary prevention. Report of the Advisory Committee on Childhood Lead Poisoning Prevention of the Centers for Disease Control and Prevention.

ATSDR, 2007. Toxicological profile for lead. United States department of health and human services: Public health service, Agency for toxic substances and disease registry. 
Beak, D.G., N.T. Basta, K.G. Scheckel, and S.J. Traina. 2008. Linking solid phase speciation of $\mathrm{Pb}$ sequestered to birnessite to oral $\mathrm{Pb}$ bioaccessibility: Implications for soil remediation. Environ. Sci. Technol. 42:779-785.

Brown, S., R.L. Chaney, J.G. Hallfrisch, and Q. Xue. 2003. Effect of biosolids processing on lead bioavailability in an urban soil. J. Environ. Qual. 32:100-108.

Brown, S., R. Chaney, J. Hallfrisch, J.A. Ryan and W.R. Berti. 2004. In situ soil treatments to reduce the phyto- and bioavailability of lead, zinc, and cadmium. J. Environ. Qual. $33: 522-531$.

Brown, S.L., I. Clausen, M.A. Chappell, K.G. Scheckel, M. Newville, and G.M. Hettiarachchi. 2012. High-iron biosolids compost-induced changes in lead and arsenic speciation and bioaccessibility in co-contaminated soils. J. Environ. Qual. 41:16121622.

Carey, A.E., J.A. Gowen, T.J. Forehand, H. Tai, and G.B. Wiersma. 1980. Heavy metal concentrations in soils of five United States cities, 1972 urban soils monitoring program. Pestic. Monit. J. 13:150-154.

Chaoui, H.I., L.M. Zibilske, and T. Ohno. 2003. Effects of earthworm casts and compost on soil microbial activity and plant nutrient availability. Soil Biol. Biochem. 35:295-302.

Codling, E. E., R. Chaney, and C. E. Green. Lead and arsenic uptake by carrots grown on five orchard soils with history of lead-arsenate application. Paper presented at: Trace elements, heavy, metals, and nutrients in the environment. ASA, CSSA, and SSSA Annual Meetings, New Orleans, Louisiana, 4-8 Nov. Paper 246-5

Cotter-Howells, J. 1996. Lead phosphate formation in soils. Environmental Pollution 93:916. 
Cui, Y.J., Y.G. Zhu, R.H. Zhai, D.Y. Chen, Y.Z. Huang, Y. Qiu, and J.Z. Liang. 2004. Transfer of metals from soil to vegetables in an area near a smelter in Nanning, China. Environ. Int. 30:785-791.

Davenport, H. W. 1984. Physiology of the digestive tract. 3rd ed. Year book. Medical Publishers, Chicago.

Davies, D.J.A., I. Thornton, J.M. Watt, E.B. Culbard, P.G. Harvey, H.T. Delves, J.C. Sherlock, G.A. Smart, J.F.A. Thomas, and M.J. Quinn. 1990. Lead intake and blood lead in two-year-old U.K. urban children. Sci. Total Environ. 90:13-29.

Davis, A., M.V. Ruby, and P.D. Bergstrom. 1992. Bioavailability of arsenic and lead in soils from the Butte, Montana, mining district. Environ. Sci. Technol. 26:461-468.

Drexler, J.W. and W.J. Brattin. 2007. An in vitro procedure for estimation of lead relative bioavailability: With validation. Hum. Ecol. Risk Assess. 13:383-401.

Ekvall, L., and M. Greger. 2003. Effects of environmental biomass-producing factors on Cd uptake in two Swedish ecotypes of Pinus sylvestris. Environ. Pollut. 121:401-411.

FAO/WHO-CODEX. 1995. Codex general standard for contaminants and toxins in food and feed: Codex stan. Revised 1995, 2006, 2008, 2009, amended 2010.

Farfel, M.R., A.O. Orlova, R.L. Chaney, P.S.J. Lees, C. Rohde, and P.J. Ashley. 2005. Biosolids compost amendment for reducing soil lead hazards: A pilot study of orgro ${ }^{\circledR}$ amendment and grass seeding in urban yards. Sci. Total Environ. 340:81-95.

Finster, M.E., K.A. Gray, and H.J. Binns. 2004. Lead levels of edibles grown in contaminated residential soils: A field survey. Sci. Total Environ. 320:245-257.

Foy, C. D., R. L. Chaney, and M. C. White. 1978. The physiology of metal toxicity in plants. Annual Review of Plant Physiology: Vol. 29: 511-566. Annual Reviews Inc. 
Furmidge, C.G.L. 1959. Physico chemical studies on agricultural sprays: The phytotoxicity of surface-active agents on leaves of apple and plum trees. Journal of the Science of Food and Agriculture. 10:274-282.

Gallardo-Lara, F., and R. Nogales. 1987. Effect of the application of town refuse compost on the soil-plant system: A review. Biological Wastes 19:35-62.

Ge, Y., P. Murray, and W.H. Hendershot. 2000. Trace metal speciation and bioavailability in urban soils. Environ. Pollut. 107:137-144.

Gothberg, A., M. Greger, K. Holm, and B.E. Bengtsson. 2004. Influence of nutrient levels on uptake and effects of mercury, cadmium, and lead in water spinach. J. Environ. Qual. $33: 1247-1255$.

Helmke, P.A., and D.L. Sparks. 1996. Lithium sodium potassium rubidium and cesium. P.551. In Sparks, D.L., A.L. Page, P.A. Helmke, R.H. Loeppert, P.N. Soltanpour, M.A. Tabatabai, C.T. Johnston, M.E. Sumner (eds.) Methods of soil analysis: Part 3, Chemical methods. SSSA, Wisconsin, USA.

Heredia, A., and E. Dominguez. 2009. The plant cuticle: A complex lipid barrier between the plant and the environment: An overview. In C. Dishovsky and A. Pivovaro (ed.) Counteraction to chemical and biological terrorism in East European countries: Proceedings of the NATO Advanced Research Workshop. p. 109-116. Springer, Dordrecht, The Netherlands

Hettiarachchi, G.M., G.M. Pierzynski, and M.D. Ransom. 2000. In situ stabilization of soil lead using phosphorus and manganese oxide. Environ. Sci. Technol. 34:4614-4619. Hettiarachchi, G.M., G.M. Pierzynski, F.W. Oehme, O. Sonmez, and J.A. Ryan. 2003. Treatment of contaminated soil with phosphorus and manganese oxide reduces lead absorption by Sprague-Dawley rats. J. Environ. Qual. 32:1335-1345. 
Hettiarachchi, G.M., and Pierzynski, G.M. 2004. Soil lead bioavailability and in situ remediation of lead contaminated soils: A review. Environ Prog. 23:78-93.

Huang, J.W. and S.D. Cunningham. 1996. Lead phytoextraction: Species variation in lead uptake and translocation. New Phytol. 134:75-84.

Hynes, H.P., and H. Genevieve. 2004. Urban horticulture in the contemporary United States: personal and community benefits. Acta Hort. 643:171-181.

James, H.M., M.E. Hilburn and J.A. Blair. 1985. Effects of meals and meal times on uptake of lead from the gastrointestinal tract in humans. Hum. Toxicol. 4:401-407.

JECFA (Joint FAO/WHO expert Committee on Food Additives). 1993. Evaluation of certain food additives and contaminants: 41st report of the Joint FAO/WHO expert Committee on Food Additives. Technical Reports Series No. 837.

Jim, C.Y. 1998. Urban soil characteristics and limitations for landscape planting in Hong Kong. Landscape and urban planning. 40:235-249.

Khaleel, R., K.R. Reddy and M.R. Overcash. 1981. Changes in soil physical properties due to organic waste applications: A Review1. J. Environ. Qual. 10:133-141.

Klein, D.H. 1972. Mercury and other metals in urban soils. Environ. Sci. Technol. 6:560562.

Lanphear, B.P., and K.J. Roghmann. 1997. Pathways of lead exposure in urban children. Environ. Res. 74:67-73.

Ma, Q.Y., T.J. Logan, and S.J. Traina. 1995. Lead immobilization from aqueous solutions and contaminated soils using phosphate rocks. Environ. Sci. Technol. 29:1118-1126.

Marr, C.W., T. Carey, R. Cloyd, and M. Kennelly. 2010. Kansas garden guide. Kansas State University, Agricultural Experiment Station and Cooperative Extension Service. http://www.ksre.ksu.edu/library/hort2/s51.pdf (accessed 21 Aug. 2012). 
Mehlich, A. 1984. Mehlich 3 soil test extractant: A modification of Mehlich 2 extractant. Commun. Soil Sci. Plant Anal. 15:1409-1416.

Mielke, H.W., J.C. Anderson, K.J. Berry, P.W. Mielke, R.L. Chaney and M. Leech. 1983. Lead concentrations in inner-city soils as a factor in the child lead problem. Am. J. Public Health 73:1366-1369.

Mulvaney, R.L. 1996. Nitrogen: Inorganic forms. p.1123. In Sparks, D.L., A.L. Page, P.A. Helmke, R.H. Loeppert, P.N. Soltanpour, M.A. Tabatabai, C.T. Johnston, M.E. Sumner (eds.) Methods of soil analysis: Part 3, Chemical methods. SSSA, Wisconsin,USA.

Nabulo, G., H. Oryem-Origa, and M. Diamond. 2006. Assessment of lead, cadmium, and zinc contamination of roadside soils, surface films, and vegetables in Kampala City, Uganda. Environ. Res. 101:42-52.

Nabulo, G., S.D. Young, and C.R. Black. 2010. Assessing risk to human health from tropical leafy vegetables grown on contaminated urban soils. Sci. Total Environ. 408:5338-5351.

Nelson, D.W., and L.E. Sommers. 1996. Total carbon organic carbon and organic matter. p. 961. In Sparks, D.L., A.L. Page, P.A. Helmke, R.H. Loeppert, P.N. Soltanpour, M.A. Tabatabai, C.T. Johnston, M.E. Sumner (eds.) Methods of soil analysis: Part 3, Chemical methods. SSSA, Wisconsin, USA.

Pennington, J.A., A. D. Bowe, and H.N. Church. 1998. Bowes and church's food values of portions commonly used. $17^{\text {th }}$ ed. Lippincott Williams \& Wilkins: Philadelphia.

Rodrigue, J., C. Comtois, and B. Slack. 2009. The Geography of Transport Systems. $2^{\text {nd }}$ ed. Routledge. New York, NY.

Ruby, M.V., A. Davis, R. Schoof, S. Eberle, and C.M. Sellstone. 1996. Estimation of lead and arsenic bioavailability using a physiologically based extraction test. Environ. Sci. Technol. 30:422-430. 
Ryan, J.A., K.G. Scheckel, W.R. Berti, S.L. Brown, S.W. Casteel, R.L. Chaney, J. Hallfrisch, M. Doolan, P. Grevatt, M. Maddaloni and D. Mosby. 2004. Peer reviewed: Reducing children's risk from lead in soil. Environ. Sci. Technol. 38:18A-24A.

SAS Institute. 2010. Companion for windows. Release 9.2. SAS Inst., Cary, NC.

Sauve, S., M. McBride, and W. Hendershot. 1998. Soil solution speciation of lead (II): Effects of organic matter and pH. Soil Sci. Soc. Am. J. 62:618-621.

Smith, E., I.M. Kempson, A.L. Juhasz, J. Weber, A. Rofe, D. Gancarz, R. Naidu, R.G. McLaren and M. Grafe. 2011. In vivo-in vitro and XANES spectroscopy assessments of lead bioavailability in contaminated periurban soils. Environ. Sci. Technol. 45:61456152

Sonneveld, C., and J. Van den Ende. 1971. Soil analysis by means of a 1:2 volume extract. Plant and Soil. 35:505-516.

Sterrett, S.B., R.L. Chaney, C.H. Gifford, and H.W. Mielke. 1996. Influence of fertilizer and sewage sludge compost on yield and heavy metal accumulation by lettuce grown in urban soils. Environmental Geochemistry and Health. 18:135-142.

Strawn, D.G., and D.L. Sparks. 2000. Effects of soil organic matter on the kinetics and mechanisms of $\mathrm{Pb}$ (II) sorption and desorption in soil. Soil Sci. Soc. Am. J. 64:144-156.

Turer, D., J. Maynard Barry, and J. Sansalone. 2001. Heavy metal contamination in soils of urban highways comparison between runoff and soil concentrations at Cincinnati, Ohio. Water, Air, \& Soil Pollution.132:293-314.

USDA. 2012. Urban agriculture. Alternative farming systems information center. National Agricultural Library, U.S. Department of Agriculture. http://afsic.nal.usda.gov/farmsand-community/urban-agriculture (accessed 20 Aug. 2012).

USEPA. 2003. Recommendations of the technical review workgroup for lead for an approach to assessing risks associated with adult exposures to lead in Soil. USEPA 540-R-03-001. 
Technical review, workshop for lead. U.S. Environmental Protection Agency. http://www.epa.gov/superfund/lead/products/adultpb.pdf (accessed 30 Aug. 2013)

USEPA. 2007a. Method 3015A: Microwave assisted acid digestion of aqueous samples and extracts. Test methods. U.S. Environmental Protection Agency. http:/www.epa.gov/epawaste/hazard/testmethods/sw846/pdfs/3015a.pdf (accessed 20 Aug. 2012).

USEPA. 2007b. Method 3051A: Microwave assisted acid digestion of sediments, sludges, soils and oils. Test methods. U.S. Environmental Protection Agency. http://www.epa.gov/epawaste/hazard/testmethods/sw846/pdfs/3051a.pdf (accessed 20 Aug. 2012).

USEPA. 2007c. Use of in vitro bioaccessibility/relative bioavailability estimates for metals in regulatory settings: what is needed. Panel Discussion Session II. Proceedings: ISEA Bioavailability Symposium Durham, North Carolina. Technical Workgroup Bioavailability Committee, U.S. Environmental Protection Agency.

USEPA. 2012. Standard operating procedure for an in vitro bioaccessibility assay for lead in soil. USEPA 9200.2-86. U.S. Environmental Protection Agency. http://epa.gov/superfund/bioavailability/pdfs/EPA_Pb_IVBA_SOP 040412 FINAL SRC.p df (accessed 06 July 2013).

USEPA.2013. Lead safe yard data: Background levels. http://www.epa.gov/region1/leadsafe/figure4.html (accessed 16 Apr. 2013).

Vega, F.A., E.F. Covelo, and M.L. Andrade. 2009. Effects of sewage sludge and barley straw treatment on the sorption and retention of $\mathrm{Cu}, \mathrm{Cd}$ and $\mathrm{Pb}$ by copper mine anthropic regosols. J. Hazard. Mater. 169:36-45. 
Yang, J., D.E. Mosby, S.W. Casteel, and R.W. Blanchar. 2001. Lead immobilization using phosphoric acid in a smelter-contaminated urban soil. Environ. Sci. Technol. 35:35533559.

You, S., Y. Yin, and H.E. Allen. 1999. Partitioning of organic matter in soils: Effects of pH and water/soil ratio. Sci. Total Environ. 227:155-160.

Zhai, M., H.A.B. Kampunzu, M.P. Modisi, and O. Totolo. 2003. Distribution of heavy metals in Gaborone urban soils (Botswana) and its relationship to soil pollution and bedrock composition. Environ. Geol. 45:171-180.

Zimdahl, R.L., and R.K. Skogerboe. 1977. Behavior of lead in soil. Environ. Sci. Technol. $11: 1202-1207$.

\section{Figure Captions}

Figure 1. Distribution of soil total $\mathrm{Pb}$ concentrations in the site and locations of test plots in 2009 and 2010 and community sample points.

Figure 2. Relationship of soil bioaccessible $\mathrm{Pb}$ in the $<2 \mathrm{~mm}$ size soil fraction to soil total $\mathrm{Pb}$ concentration in the same fraction.

Figure 3: Relationship between percentage of bioaccessible $\mathrm{Pb}$ and soil Mehlich III-P in the $<$ $2 \mathrm{~mm}$ size soil fraction 16 days after compost addition.

Figure 4. Comparison of vegetable $\mathrm{Pb}$ concentrations with maximum allowable levels $\dagger$ of $\mathrm{Pb}$ in vegetables. $\uparrow$ Maximum allowable levels: leafy vegetables, $0.3 \mathrm{mg} \mathrm{kg}^{-1}$-fresh weight; fruiting vegetables, root and tuber crops, $0.1 \mathrm{mg} \mathrm{kg}^{-1}$-fresh weight (FAO/WHO-CODEX, 1995; 2010 amendment). (A) Swiss chard in 2010; $\mathrm{ML}=5.0 \mathrm{mg} \mathrm{kg}^{-1}$-dry weight, moisture 
content 94\%. (B) Tomato in 2010; $\mathrm{ML}=1.6 \mathrm{mg} \mathrm{kg}^{-1}$-dry weight, moisture content $94 \%$. (C) Carrot in 2010; $\mathrm{ML}=1.5 \mathrm{mg} \mathrm{kg}^{-1}$-dry weight, moisture content 93\%. (D) Vegetables in 2009; ML 5.0, 1.6 and $1.5 \mathrm{mg} \mathrm{kg}^{-1}$ as in (A), (B), and (C) respectively. *, ** Two categories are significantly different at 0.05 probability level. Different letters indicates the significance difference within the category at 0.05 probability level and similar letters indicates no significant difference within the category.

Figure 5. Relationship of $\mathrm{Pb}$ concentrations of vegetables to soil total $\mathrm{Pb}$ concentrations in 2009 and 2010 test plots and 2010 community samples. 
Table 1. Selected nutrients and fertility parameters in preliminary soil samples (soil), compost, and plot soils at planting and at harvest of vegetables (in 2010).

\begin{tabular}{|c|c|c|c|c|c|c|c|c|c|c|}
\hline & \multirow[t]{5}{*}{ Soil } & \multirow[t]{5}{*}{ Compost } & \multicolumn{4}{|c|}{ No-compost plot soils } & \multicolumn{4}{|c|}{ Compost-added plot soils† } \\
\hline & & & \multirow[b]{2}{*}{ At planting } & \multicolumn{3}{|c|}{ At harvest } & \multirow[b]{2}{*}{ At planting } & \multicolumn{3}{|c|}{ At harvest } \\
\hline & & & & $\begin{array}{l}\text { Swiss } \\
\text { chard }\end{array}$ & Tomato & Carrot & & $\begin{array}{l}\text { Swiss } \\
\text { chard }\end{array}$ & Tomato & Carrot \\
\hline & & & \multicolumn{8}{|c|}{ Days after compost addition } \\
\hline & & & 16 & 69 & 105 & 121 & 16 & 69 & 105 & 121 \\
\hline Total $\mathrm{Pb}, \mathrm{mg} \mathrm{kg}^{-1}$ & $68-305$ & 24 & $208 \pm 14 \div$ & - & - & - & $146 \pm 13 \ddagger$ & - & - & - \\
\hline $\mathrm{pH}$ (1:10 soil: water) & 6.80 & 8.5 & 6.9 & 7.1 & 7.1 & 6.7 & $7.60 \backslash$ & 7.5 & 7.6 & 7.0 \\
\hline $\mathrm{CEC}$ -, $\mathrm{cmol}_{+} \mathrm{kg}^{-1}$ & - & - & 20.4 & - & - & - & 33.8 & - & - & - \\
\hline Sand, silt and clay, $\%$ & $4,75,21$ & - & & - & - & - & - & - & - & - \\
\hline Organic C, \% & - & 21 & 2.1 & $0.9 \pm 0.1 \S$ & $0.9 \pm 0.1 \S$ & $1.0 \pm 0.1 \S$ & 3.2 & $3.1 \pm 0.2 \S$ & $2.7 \pm 0.1 \S$ & $2.9 \pm 0.1 \S$ \\
\hline $\mathrm{DOC}^{\#}, \mathrm{mg} \mathrm{L}^{-1}$ & - & - & 51 & - & 18 & 18 & 158 & 45 & 47 & 44 \\
\hline $\begin{array}{l}\text { Electrical } \\
\text { conductivity, } \mathrm{dS} \mathrm{m}^{-1}\end{array}$ & 0.19 & 5.6 & - & - & - & - & - & - & - & - \\
\hline Total $\mathrm{N}, \mathrm{mg} \mathrm{kg}^{-1}$ & 1907 & 13470 & & & & & & & & \\
\hline Available $\mathrm{N}, \mathrm{mg} \mathrm{kg}^{-1}$ & $13-127$ & 555 & $18 \pm 0$ & $28 \pm 1$ & $12 \pm 1$ & $16 \pm 2$ & $279 \pm 18$ & $46 \pm 4$ & $29 \pm 3$ & $30 \pm 2$ \\
\hline Mehlich III-P, $\mathrm{mg} \mathrm{kg}^{-1}$ & $57-154$ & - & $68 \pm 06$ & $57 \pm 8$ & $63 \pm 11$ & $58 \pm 10$ & $438 \pm 25$ & $355 \pm 23$ & $264 \pm 28$ & $279 \pm 14$ \\
\hline Available $\mathrm{K}, \mathrm{mg} \mathrm{kg}^{-1}$ & $225-624$ & - & $328 \pm 20$ & $285 \pm 19$ & $310 \pm 20$ & $336 \pm 18$ & $1978 \pm 97$ & $1091 \pm 137$ & $893 \pm 15$ & $862 \pm 26$ \\
\hline $\mathrm{C}: \mathrm{N}$ ratio & & 16 & - & - & - & - & - & - & - & - \\
\hline Total $\mathrm{P}, \mathrm{mg} \mathrm{kg}^{-1}$ & - & 3150 & - & - & - & - & - & - & - & - \\
\hline Total Fe, $\mathrm{mg} \mathrm{kg}^{-1}$ & - & 6280 & - & - & - & - & - & - & - & - \\
\hline Total Mn, $\mathrm{mg} \mathrm{kg}^{-1}$ & - & 397 & - & - & - & - & - & - & - & - \\
\hline
\end{tabular}

$\uparrow$ Rate of compost- $28 \mathrm{~kg} \mathrm{~m}^{-2}$

tAverage and standard error of 12 blocks: 4 blocks for each of 3 vegetable crops.

$\S$ Average and standard error of 4 blocks.

-Cation Exchange Capacity.

\# Dissolved organic C in 1:2 soil:water (v/v) extract 
Table 2. Soil bioaccessible $\mathrm{Pb}$ in tomato-growing plots as determined at $\mathrm{pH} 1.5$.

\begin{tabular}{|c|c|c|c|c|c|}
\hline \multirow{3}{*}{$\begin{array}{l} \\
\\
<2 \text { mm fraction } \\
\text { (Whole soil) }\end{array}$} & \multicolumn{2}{|c|}{$\begin{array}{l}16 \text { days after adding compost } \\
\text { (at planting) }\end{array}$} & \multicolumn{2}{|c|}{$\begin{array}{l}105 \text { days after adding compost } \\
\text { (at harvesting) }\end{array}$} & \multirow{2}{*}{$\begin{array}{c}\text { Standard soil } \\
\% \text { bioaccessible } \\
\mathrm{Pb}\end{array}$} \\
\hline & $\begin{array}{c}\text { Bioaccessible } \\
\mathrm{Pb} \\
\end{array}$ & $\begin{array}{c}\% \text { bioaccessible } \\
\mathrm{Pb}^{\dagger}\end{array}$ & $\begin{array}{c}\text { Bioaccessible } \\
\mathrm{Pb} \\
\end{array}$ & $\begin{array}{c}\% \text { bioaccessible } \\
\mathrm{Pb}\end{array}$ & \\
\hline & $\mathrm{mg} \mathrm{kg}^{-1}$ & & $\mathrm{mg} \mathrm{kg}^{-1}$ & & \\
\hline No compost & $57.4 \pm 5.0 *+$ & $37.5 \pm 2.5 * *$ & $55.6 \pm 7.0$ & $33.6 \pm 3.5$ & - \\
\hline Compost & $44.1 \pm 6.0 *$ & $28.7 \pm 1.7 * *$ & $46.2 \pm 11.0$ & $26.1 \pm 3.3$ & - \\
\hline \multicolumn{6}{|l|}{$<250 \mu \mathrm{m}$ fraction } \\
\hline No compost & $78.7 \pm 19.5$ & $32.9 \pm 2.3^{*}$ & $84.4 \pm 27.5$ & $35.4 \pm 1.5 * *$ & - \\
\hline Compost & $53.9 \pm 6.8$ & $29.0 \pm 1.0^{*}$ & $56.7 \pm 5.7$ & $26.7 \pm 0.8 * *$ & - \\
\hline NIST $2711 \mathrm{a}$ & - & - & - & - & $78.9 \S$ \\
\hline $\begin{array}{l}* \text { Two values in the } \\
* * \text { Two values in th } \\
\dagger \text { Bioaccessible } \mathrm{Pb} \\
\text { calculate percentag } \\
\text { tStandard error of } \\
\text { §Acceptable range }\end{array}$ & $\begin{array}{l}\text { ne column with } \\
\text { ame column wi } \\
\text { percentage of } \\
\text { bioaccessible I } \\
\text { ocks. } \\
5.2-96.2 \% \text { whe }\end{array}$ & $\begin{array}{l}\text { a size fraction } \mathrm{w} \\
\mathrm{n} \text { a size fraction } \\
1 \text { total } \mathrm{Pb} \text {. Soil to } \\
\text { in the correspond } \\
4 \mathrm{M} \text { glvcine is }\end{array}$ & $\begin{array}{l}\text { significantly } \\
\text { e significantl } \\
\mathrm{Pb} \text { in the }<2 \\
\text { fraction. }\end{array}$ & $\begin{array}{l}\text { fferent at } 0.1 \text { prob } \\
\text { different at } 0.05 \text { pr } \\
\mathrm{m} \text { or }<250 \mu \mathrm{m} \text { fra } \\
\text { nt (USEPA, } 2012\end{array}$ & $\begin{array}{l}\text { ility level. } \\
\text { ability level. } \\
\text { ion was used to }\end{array}$ \\
\hline
\end{tabular}


Table 3. Soil bioaccessible $\mathrm{Pb}$ in tomato-growing plots as determined at $\mathrm{pH} 2.5$.

\begin{tabular}{|c|c|c|c|c|c|}
\hline & \multicolumn{2}{|c|}{$\begin{array}{l}16 \text { days after adding compost } \\
\text { (at planting) }\end{array}$} & \multicolumn{2}{|c|}{$\begin{array}{l}105 \text { days after adding compost } \\
\text { (at harvesting) }\end{array}$} & \multirow{2}{*}{$\begin{array}{c}\text { Standard soil } \\
\% \text { bioaccessible } \\
\mathrm{Pb} \\
\end{array}$} \\
\hline & $\begin{array}{c}\text { Bioaccessible } \\
\mathrm{Pb}\end{array}$ & $\begin{array}{c}\text { \% bioaccessible } \\
\mathrm{Pb} \dagger\end{array}$ & $\begin{array}{c}\text { Bioaccessible } \\
\mathrm{Pb}\end{array}$ & $\begin{array}{c}\text { \% bioaccessible } \\
\mathrm{Pb}\end{array}$ & \\
\hline & $\mathrm{mg} \mathrm{kg}^{-1}$ & & $\mathrm{mg} \mathrm{kg}^{-1}$ & & \\
\hline \multicolumn{6}{|l|}{$\begin{array}{l}<2 \mathrm{~mm} \text { fraction } \\
(\text { Whole soil })\end{array}$} \\
\hline No compost & $13.4 \pm 6.4 \%$ & $6.3 \pm 2.0$ & $12.1 \pm 3.4$ & $5.2 \pm 1.3$ & - \\
\hline Compost & $9.2 \pm 1.3$ & $6.0 \pm 0.4^{*}$ & $6.4 \pm 1.8$ & $3.6 \pm 0.6^{*}$ & - \\
\hline \multicolumn{6}{|l|}{$<250 \mu \mathrm{m}$ fraction } \\
\hline No compost & $14.1 \pm 4.8$ & $5.6 \pm 0.9^{* *}$ & $12.8 \pm 5.1$ & $5.1 \pm 0.5 * * *$ & - \\
\hline Compost & $7.4 \pm 1.4$ & $3.9 \pm 0.4 * *$ & $8.5 \pm 1.8$ & $3.9 \pm 0.5^{* * *}$ & - \\
\hline NIST $2711 \mathrm{a}$ & - & - & - & - & 35.2 \\
\hline $\begin{array}{l}\text { Two values in the } \\
* \text { Two values in the } \\
* * \text { Two values in th } \\
\text { Bioaccessible } \mathrm{Pb} \text { a } \\
\text { alculate percentage } \\
\text { Standard error of } 4\end{array}$ & $\begin{array}{l}\text { e row within a } \\
\text { ne column wit } \\
\text { me column wi } \\
\text { ercentage of s } \\
\text { ioaccessible P } \\
\text { cks. }\end{array}$ & $\begin{array}{l}\text { ze fraction were } \\
\text { a size fraction } \\
\text { in a size fraction } \\
\text { total } \mathrm{Pb} \text {. Soil tot } \\
\text { in the corresponc }\end{array}$ & $\begin{array}{l}\text { nificantly diff } \\
\text { e significantl } \\
\text { re significantl } \\
\text { b in the }<2 n \\
\text { fraction. }\end{array}$ & $\begin{array}{l}\text { nt at } 0.15 \text { probabi } \\
\text { fferent at } 0.15 \text { pro } \\
\text { ifferent at } 0.1 \text { pro } \\
\text { or }<250 \mu \mathrm{m} \text { fract }\end{array}$ & $\begin{array}{l}\text { ty level. } \\
\text { ability level. } \\
\text { bility level. } \\
\text { n was used to }\end{array}$ \\
\hline
\end{tabular}


Table 4. Selected chemical properties of soils ${ }^{\dagger}$ and $\mathrm{Pb}$ concentrations in vegetables (in 2009).

\begin{tabular}{|c|c|c|c|c|c|}
\hline & Soil total $\mathrm{Pb}$ & Soil pH & Mehlich III-P & Vegetable $\mathrm{Pb}$ & $\mathrm{BCF} \xi$ \\
\hline & $\mathrm{mg} \mathrm{kg}^{-1}$ & & $\mathrm{mg} \mathrm{kg}^{-1}$ & $\begin{array}{c}\mathrm{mg} \mathrm{kg}^{-1} \text {, dry } \\
\text { weight }\end{array}$ & \\
\hline \multicolumn{6}{|l|}{ Experiment plots } \\
\hline \multicolumn{6}{|l|}{ No compost } \\
\hline Swiss chard & $95 \pm 13$ & 6.92 & $99 \pm 6$ & $0.39 \pm 0.12$ & 0.0052 \\
\hline Tomato & $123 \pm 21$ & 7.03 & $103 \pm 2$ & $0.07 \pm 0.00$ & 0.0006 \\
\hline Sweet potato & $105 \pm 8$ & 7.05 & $99 \pm 7$ & $0.83 \pm 0.12$ & 0.0081 \\
\hline \multicolumn{6}{|l|}{ Compost } \\
\hline Swiss chard & $81 \pm 4$ & 7.88 & $215 \pm 10$ & $0.26 \pm 0.03$ & 0.0032 \\
\hline Tomato & $97 \pm 11$ & 8.06 & $260 \pm 22$ & $0.07 \pm 0.01$ & 0.0008 \\
\hline Sweet potato & $102 \pm 16$ & 7.99 & $240 \pm 29$ & $1.32 \pm 0.11$ & 0.0132 \\
\hline \multicolumn{6}{|l|}{ Community samples 9} \\
\hline Swiss chard A & & & & 0.89 & \\
\hline Swiss chard B & & & & 0.98 & \\
\hline Mustard A & & & & 0.17 & \\
\hline Mustard B & & & & 0.27 & \\
\hline Carrot & & & & 1.03 & \\
\hline
\end{tabular}

$\dagger$ Soils collected immediately after adding compost to the experiment plots.

$\$ \mathrm{~Pb}$ concentrations of edible portion of vegetables in dry weight basis determined after washing with the lab cleaning technique.

$\S$ Bioconcentration factor: ratio of $\mathrm{Pb}$ concentration in the edible portion of plant and total $\mathrm{Pb}$ concentration in soil.

I Randomly collected plant samples from the rest of the garden. Varieties of plants were not known; different varieties are indicated by A and B. Gardeners added compost prior to planting. 
Table 5. Selected chemical properties of soils ${ }^{\dagger}$ and $\mathrm{Pb}$ concentrations in vegetables (in 2010).

\begin{tabular}{|c|c|c|c|c|c|c|}
\hline & Soil total $\mathrm{Pb}$ & $\begin{array}{l}\mathrm{Sr}\left(\mathrm{NO}_{3}\right)_{2-} \\
\text { extractable soil } \\
\mathrm{Pb}\end{array}$ & Soil pH & Mehlich P & Vegetable $\mathrm{Pb} \ddagger$ & $\mathrm{BCF} \S$ \\
\hline & $\mathrm{mg} \mathrm{kg}^{-1}$ & $\mathrm{mg} \mathrm{kg}^{-1}$ & & $\mathrm{mg} \mathrm{kg}^{-1}$ & $\mathrm{mg} \mathrm{kg}^{-1}$, dry weight & \\
\hline \multicolumn{7}{|l|}{ Experiment plots } \\
\hline \multicolumn{7}{|l|}{ No compost } \\
\hline Swiss chard & $221 \pm 47$ & $<0.005$ & 6.93 & $62 \pm 10$ & $0.71 \pm 0.084 * *$ & 0.0037 \\
\hline Tomato & $189 \pm 28$ & $<0.005$ & 6.88 & $75 \pm 09$ & $0.09 \pm 0.029$ & 0.0005 \\
\hline Carrot & $224 \pm 55$ & $<0.005$ & 6.97 & $68 \pm 12$ & $1.37 \pm 0.179 * *$ & 0.0112 \\
\hline \multicolumn{7}{|l|}{ Compost } \\
\hline Swiss chard & $154 \pm 35$ & $0.021 \pm 0.007$ & 7.70 & $456 \pm 44$ & $0.29 \pm 0.04 * *$ & 0.0020 \\
\hline Tomato & $153 \pm 15$ & $0.020 \pm 0.006$ & 7.57 & $450 \pm 16$ & $0.06 \pm 0.02$ & 0.0004 \\
\hline Carrot & $129 \pm 11$ & $0.020 \pm 0.005$ & 7.65 & $409 \pm 64$ & $1.41 \pm 0.23^{* *}$ & 0.0110 \\
\hline \multicolumn{7}{|l|}{ Community samples $\mathbb{q}$} \\
\hline Tomato (Red cherry) & 66 & & 7.66 & & 0.20 & 0.0030 \\
\hline Tomato (Yellow cherry) & 102 & & 7.77 & & 0.06 & 0.0006 \\
\hline Sweet pepper & 73 & & 7.85 & & 0.08 & 0.0011 \\
\hline Lettuce & 92 & & 7.87 & & 0.32 & 0.0034 \\
\hline Okra & 95 & & 7.47 & & 0.08 & 0.0009 \\
\hline
\end{tabular}

$\uparrow$ Soils collected 16 days after adding compost (at planting) to the experiment plots.

$\$ \mathrm{~Pb}$ concentrations of edible portion of vegetables in dry weight basis after washing them with the lab cleaning technique.

** Two values of the same vegetable across the compost treatments were statistically significant at 0.05 probability level.

$\S$ Bioconcentration factor: ratio of $\mathrm{Pb}$ concentration in the edible portion of plant and total $\mathrm{Pb}$ concentration in soil.

I Randomly collected soil and respective plant samples from the rest of garden. Samples were collected at harvest.

Gardeners added compost prior to planting. 
Table 6. Effects of compost addition on $\mathrm{Pb}$ concentration and total $\mathrm{Pb}$ in Swiss chard leaves (in 2010).

\begin{tabular}{lccc}
\hline & $\mathrm{Pb}$ concentration & Aboveground biomass & Total $\mathrm{Pb}$ \\
\cline { 2 - 4 } & $\mu \mathrm{g} \mathrm{kg}^{-1}$, fresh matter & $\mathrm{Kg}$, fresh mater & $\mu \mathrm{g}$, fresh matter \\
No compost & $42.3 \pm 5.1^{* *}$ & $0.92 \pm 0.19$ & $44.8 \pm 9.3$ \\
Compost & $17.2 \pm 2.6^{* *}$ & $2.54 \pm 0.30$ & $40.7 \pm 12.9$ \\
\hline
\end{tabular}

Average \pm standard error of 4 blocks.

** Two values were statistically significant at 0.05 probability level. 
Figure 1. Distribution of soil total $\mathrm{Pb}$ concentrations in the site and locations of test plots in 2009 and 2010 and community sample points.

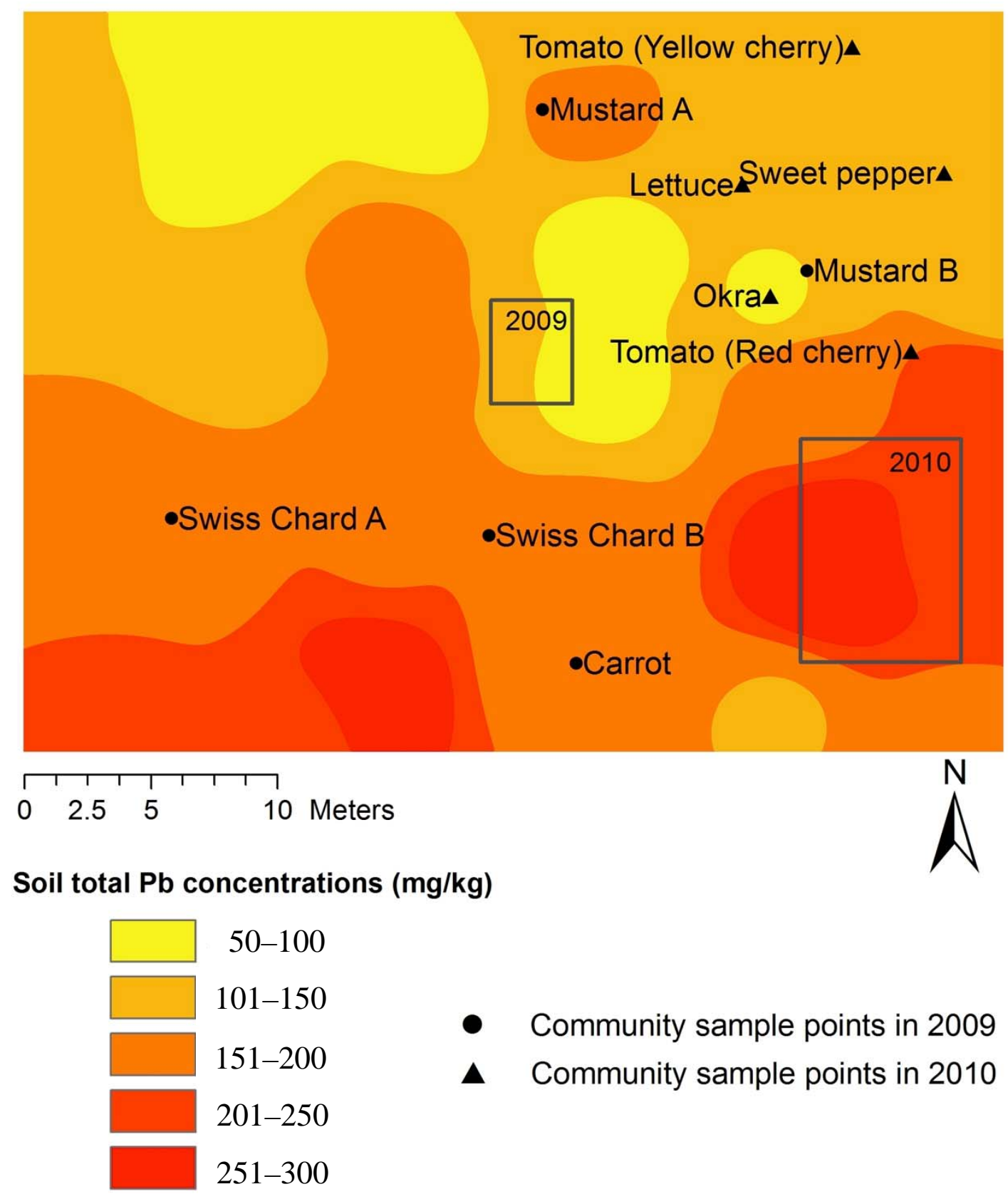


Figure 2. Relationship of soil bioaccessible $\mathrm{Pb}$ in the $<2 \mathrm{~mm}$ size soil fraction to soil total $\mathrm{Pb}$ concentration in the same fraction.

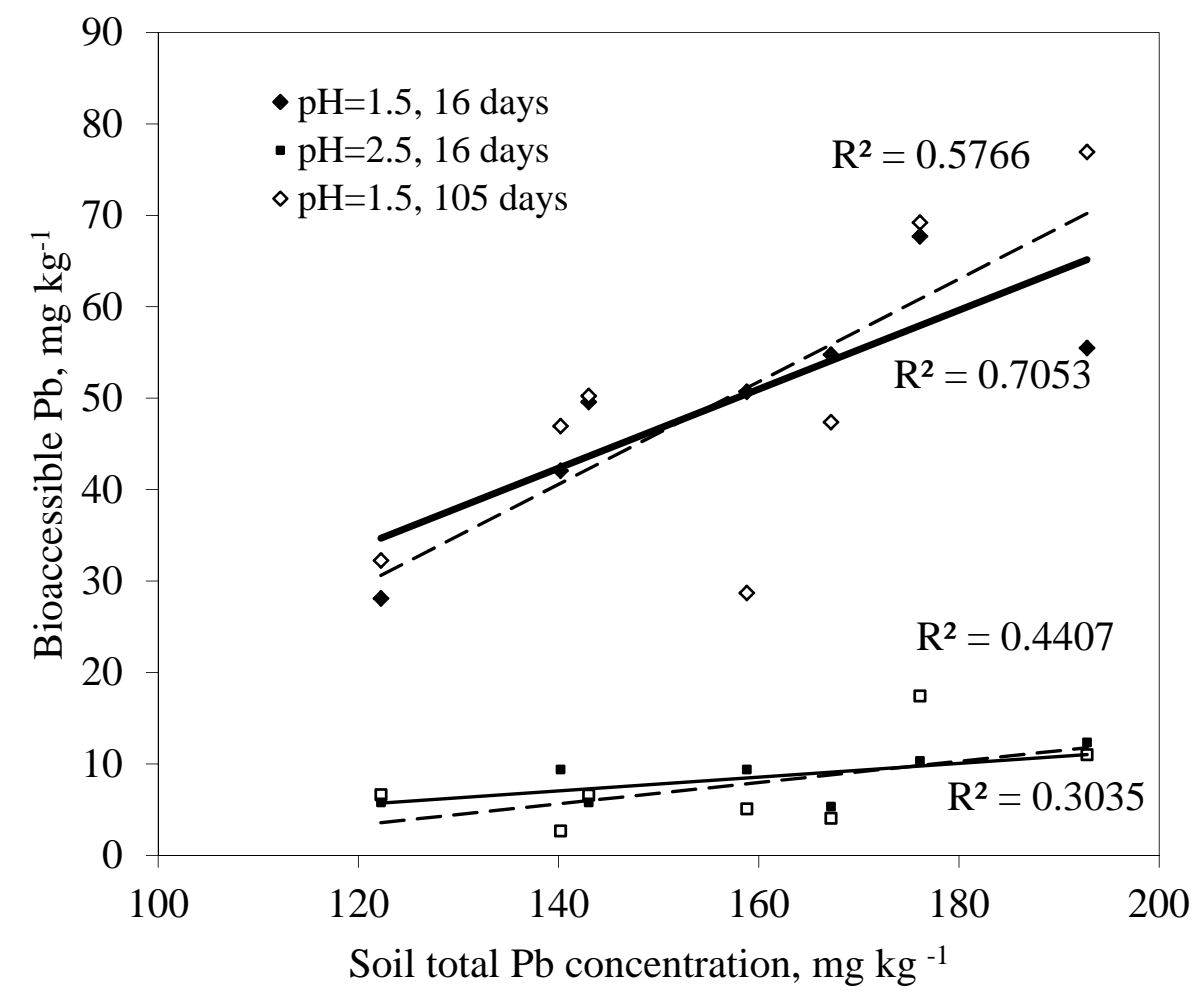


Figure 3: Relationship between percentage of bioaccessible $\mathrm{Pb}$ and soil Mehlich III-P in the $<2$ mm size soil fraction 16 days after compost addition.

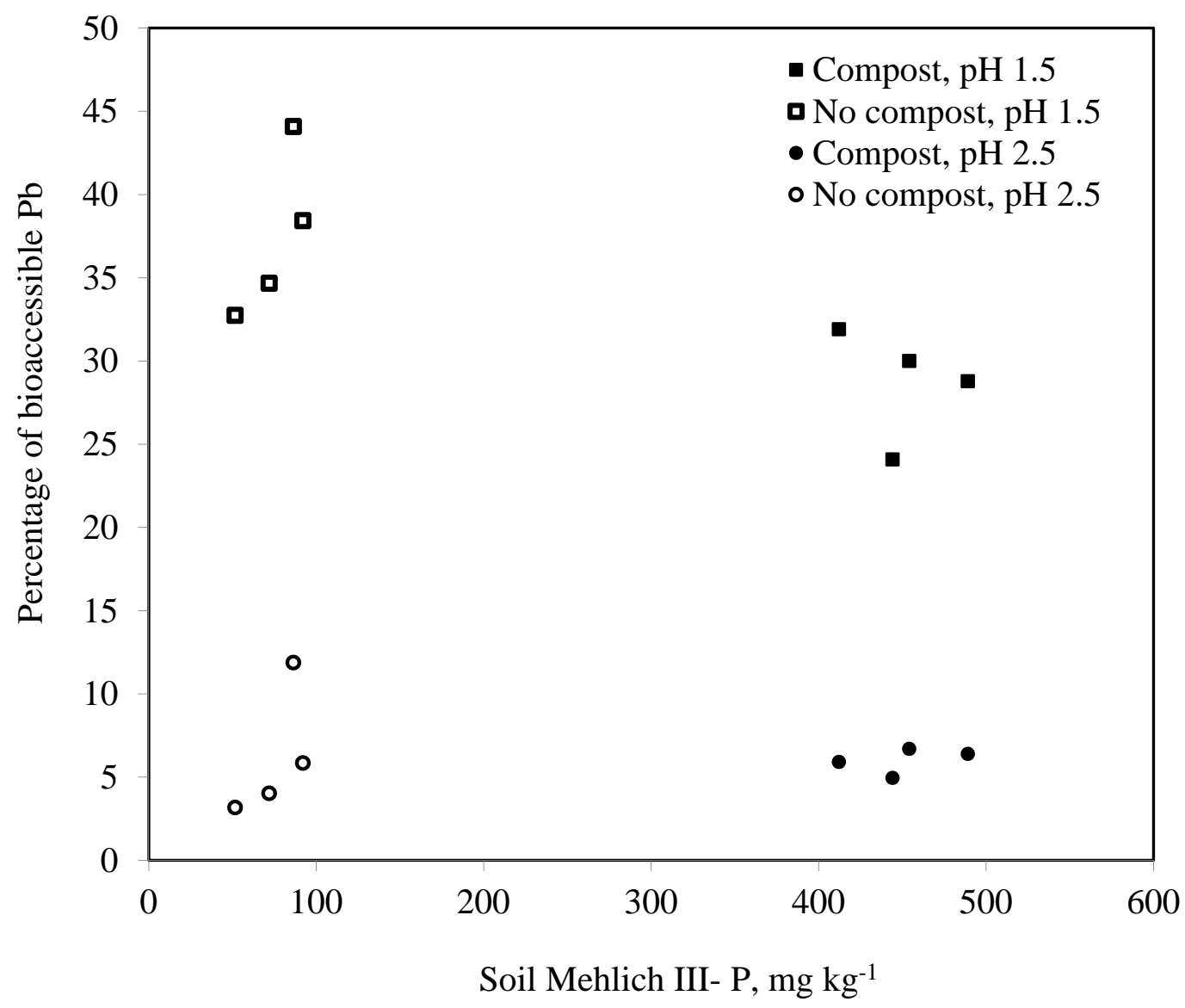



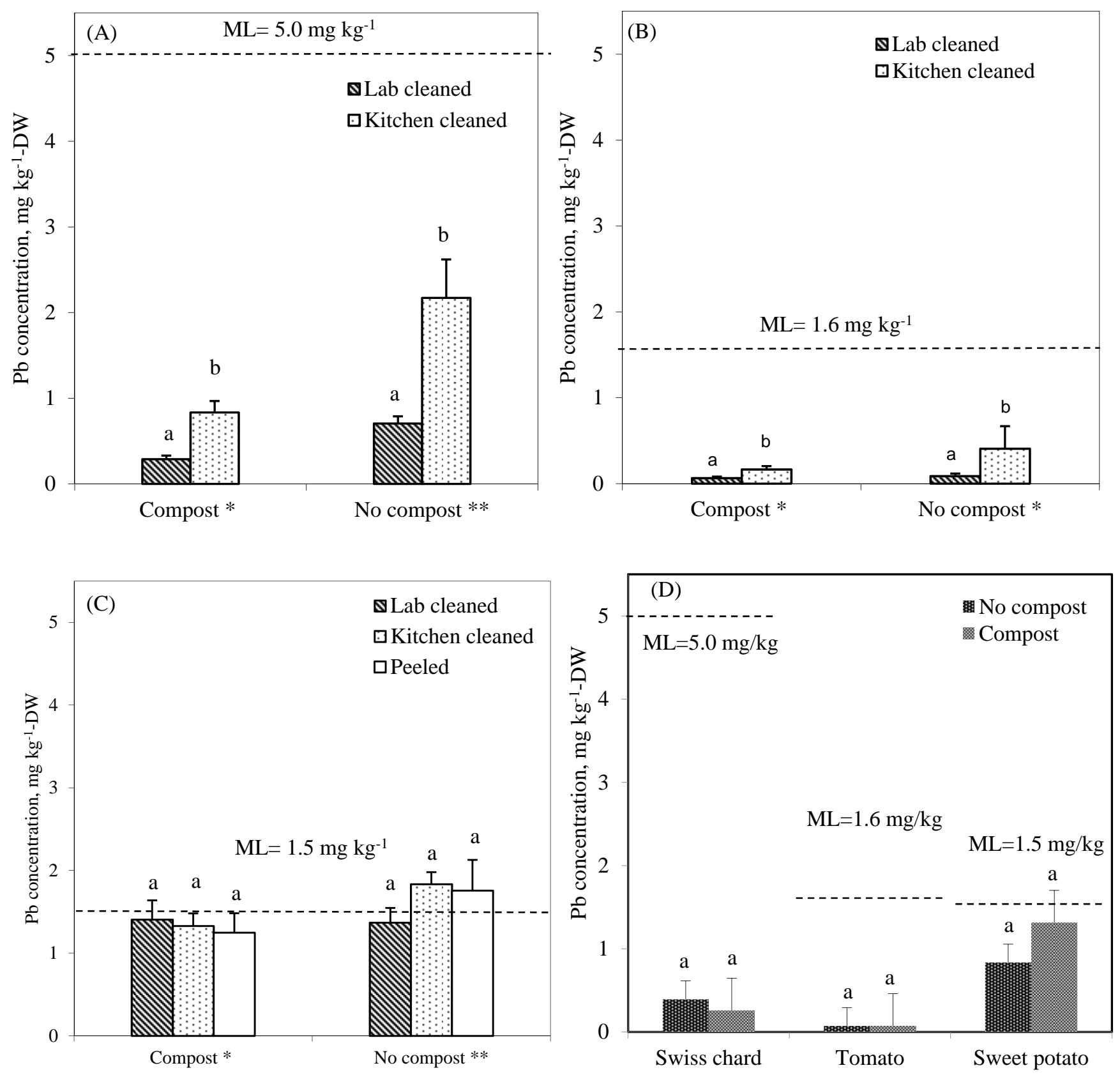

Figure 4. Comparison of vegetable $\mathrm{Pb}$ concentrations with maximum allowable levels $\dagger$ of $\mathrm{Pb}$ in vegetables. † Maximum allowable levels: leafy vegetables, $0.3 \mathrm{mg} \mathrm{kg}^{-1}$-fresh weight; fruiting vegetables, root and tuber crops, $0.1 \mathrm{mg} \mathrm{kg}^{-1}$-fresh weight (FAO/WHO-CODEX, 1995; 2010 amendment). (A) Swiss chard in 2010; ML=5.0 mg kg${ }^{1}$-dry weight, moisture content $94 \%$. (B) Tomato in 2010; $\mathrm{ML}=1.6 \mathrm{mg} \mathrm{kg}^{-1}$-dry weight, moisture content $94 \%$. (C) Carrot in 2010; ML=1.5 mg kg-1-dry weight, moisture content 93\%. (D) Vegetables in 2009; ML 5.0, 1.6 and $1.5 \mathrm{mg}$ $\mathrm{kg}^{-1}$ as in (A), (B), and (C) respectively.

*, ** Two categories are significantly different at 0.05 probability level. Different letters indicates the significance difference within the category at 0.05 probability level and similar letters indicates no significant difference within the category. 
Figure 5. Relationship of $\mathrm{Pb}$ concentrations of vegetables to soil total $\mathrm{Pb}$ concentrations in 2009 and 2010 test plots and 2010 community samples.

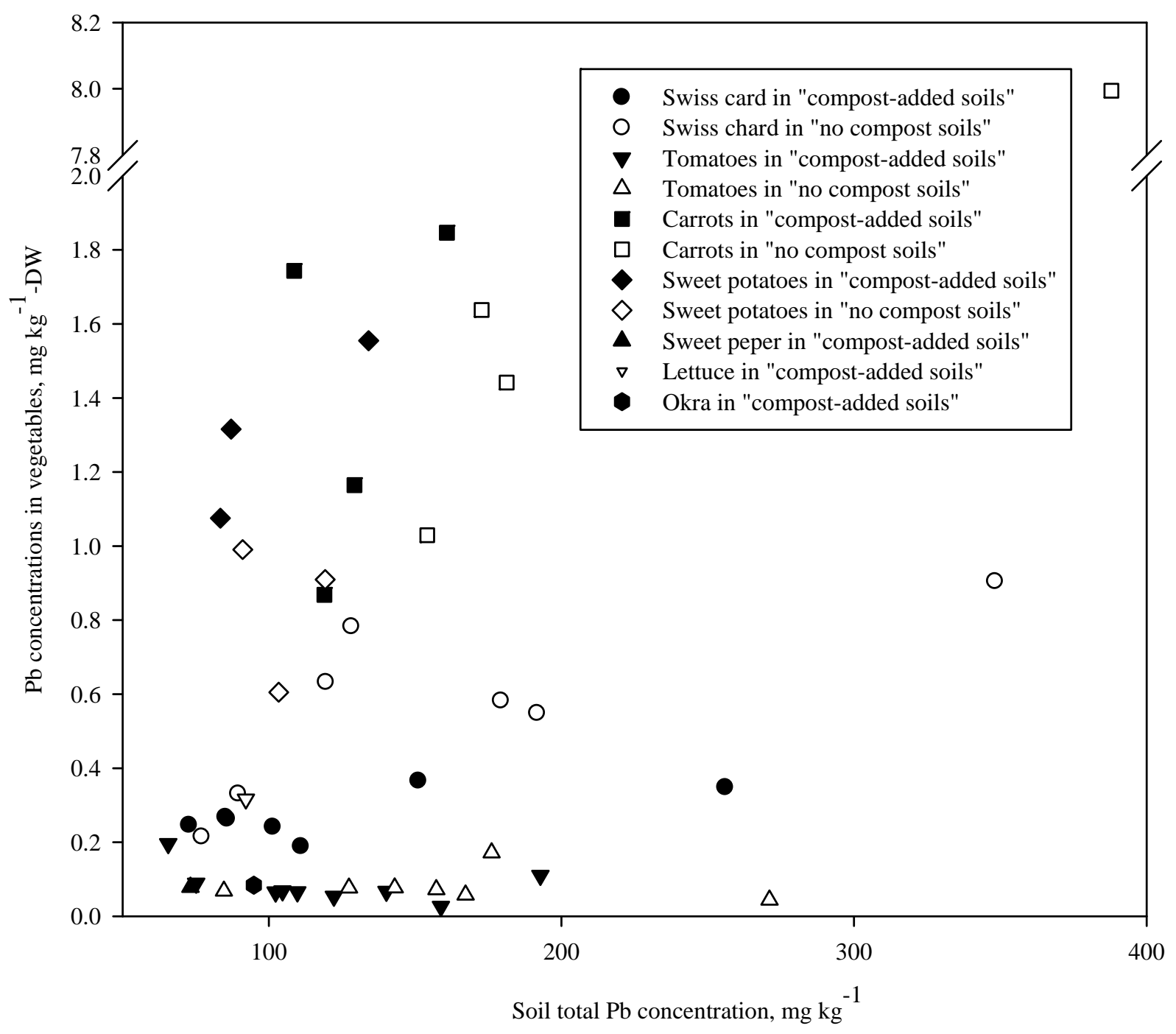

